\title{
Conhecimento, PaiXão E CONDENAÇÃo \\ a Trajetória Filosófica de Sócrates pelo Olhar \\ Cinematográfico de Roberto Rossellini
}

\author{
Thaís Conconi Silva*
}

\begin{abstract}
RESUMO
Neste artigo buscamos contextualizar o cinema como forma de estudo da história e fonte de conhecimento. Uma vez que esta linguagem pode condensar diversas visões acerca de um fenômeno, ela se apresentará como meio para o desenvolvimento de uma postura crítica e reflexiva sobre a relação cinema e história, bem como os objetos que permeiam este discurso. Analisaremos o filme Sócrates (1972) da coleção Os Filósofos, dirigida por Roberto Rossellini, buscando, através do olhar cinematográfico, reconstruir a história do filósofo e a evolução de seus pensamentos, numa perspectiva filosófica. Rossellini focaliza o caminho de Sócrates até a sua morte por cicuta, ilustrando a fidelidade do filósofo à sua própria consciência. É mostrado com certo rigor histórico conflitos e guerras, as nuances do politeísmo grego, o espírito questionador da filosofia antiga e o julgamento de Sócrates perante a Assembleia. 0 artigo analisa, de forma intertextual, as principais obras de Sócrates e aquelas que seus discípulos escreveram sobre ele como a Defesa de Sócrates, por Platão e os Ditos e feitos memoráveis de Sócrates, por Xenofonte. Incluímos, também, observações advindas de artigos científicos que versam sobre as experiências do filósofo e reflexões filosóficas realizadas por este. A análise fílmica foi feita com base nas transcrições de diálogos, imagens, luz e banda sonora, refletindo sobre conceitos de filosofia e religião presentes na obra. Pretendemos mostrar
\end{abstract}

* Doutoranda em Ciências Humanas e Sociais e Mestre em Ensino, História e Filosofia das Ciências e Matemática pela Universidade Federal do ABC - São Bernardo do Campo, São Paulo. thais.conconi@ufabc.edu.br.

Revista Páginas de Filosofia, v. 9, n. 2, p. 69-107, jul.-dez. 2020 
que o uso do cinema explorado criticamente de forma ampliada, ou seja, através dos símbolos e signos que estruturam uma base de valores estéticos e éticos em algum contexto temático e cultural, pode potencializar a construção de novos saberes e reflexões. Palavras-Chave: Sócrates; Roberto Rossellini; Neorrealismo Italiano; Filosofia.

\title{
KNOWLEDGE, PASSION AND CONDEMNATION Socrates' Philosophical Trajectory through Roberto RosSellini's Cinematographic Look.
}

\begin{abstract}
In this article we seek to contextualize cinema as a way of studying history and a source of knowledge. Since this language can condense several views about a phenomenon, it will present itself as a means for the development of a critical and reflective stance on the relationship between cinema and history, as well as the objects that permeate this discourse. We will analyze the film Socrates (1972) from the collection The Philosophers, directed by Roberto Rossellini, seeking, through the cinematographic look, to reconstruct the history of the philosopher and the evolution of his thoughts, in a philosophical perspective. Rossellini focuses on Socrates' path to his hemlock death, illustrating the philosopher's fidelity to his own conscience. It shows with certain historical rigor conflicts and wars, the nuances of Greek polytheism, the questioning spirit of ancient philosophy and the judgment of Socrates before the Assembly. The article analyzes, intertextually, the main works of Socrates and those that his disciples wrote about him as the Defense of Socrates, by Plato and the Memorable Sayings and Deeds of Socrates, by Xenophon. We also included observations from scientific articles that deal with the philosopher's experiences and philosophical reflections made by him. The film analysis was made based on the transcriptions of dialogues, images, light and soundtrack, reflecting on concepts of philosophy and religion present in the work. We intend to show that the use of cinema explored critically in a broader way, that is, through the symbols and signs that structure a base of aesthetic and ethical values in some thematic and cultural context, can enhance the construction of new knowledge and reflections. Keywords: Socrates; Roberto Rossellini; Italian Neorealism; Philosophy.
\end{abstract}


"A vida sem reflexão não vale a pena ser vivida" (Sócrates) ${ }^{1}$

\section{INTRODUÇÃo}

Roberto Rossellini, nascido em sete de maio de 1906, era um italiano de alma ardente e espírito fervoroso e cresceu em meio a uma família católica tradicional. Frequentou o jardim da infância em uma instituição religiosa, conforme era comum em sua época. Sobre a escola, o diretor posiciona-se, em sua autobiografia, de forma crítica: "Tanto esforço para aprender gramática, essas regrinhas de sintaxe perfeitamente inúteis, esses milhões de palavras zumbindo como moscas. E essa maneira de colocar o aluno em uma forma e depois apertar, apertar, para moldá-lo segundo os desejos da sociedade" (ROSSELLINI, 1992, p.80).

Para Rossellini o ensino, da forma em que fora estruturado, somente disseminava e reproduzia verdades deformadas, conhecimentos inúteis e métodos duvidosos: "A primeira coisa que a escola nos ensina é a hipocrisia; depois vem a competição e o arrivismo: “(...) Eu sabia como adornar-me com as plumas do saber, e esta aparência é tudo o que os pedagogos pedem" (ROSSELLINI, 1992, p.80).

Em carta escrita datada de 01 de janeiro de 1977, o italiano declara sua luta contra a "insignificante ficção a que se encontra reduzida a expressão audiovisual em nossa sociedade, bem como o contágio de que esta foi vítima" (ROSSELLINI, 1992, p.1). É evidente sua indignação pelo potencial desperdiçado das mídias audiovisuais:

Pela primeira vez desde que o homem existe, possuímos um meio de comunicação universal imediato, ao contrário da escrita, que supõe toda uma bagagem cultural. E em que o transformamos? Em uma espécie de jogo circense que corrompe todo o mundo e todos os seres (ROSSELLINI, 1992, p.1).

\footnotetext{
1 Frase pronunciada por Sócrates durante sua defesa perante a Assembleia. Uma pena alternativa poderia lhe ser estipulada pela lei ateniense, mas ele não poderia abandonar seu compromisso com a investigação filosófica.
}

Revista Páginas de Filosofia, v. 9, n. 2, p. 69-107, jul.-dez. 2020 
Para Rossellini, os momentos de consciência humana se tornam espetáculos como o da chegada do homem à Lua. 0 diretor faz uma pergunta retórica: "Em que tipo de palhaços nós nos transformamos?", alegando fortemente a falta de uma pedagogia coerente às técnicas que dispomos e o mal-uso feito da população mundial:

Quando nasci, em 1906, a população do globo elevava-se a um bilhão e oitocentos milhões de indivíduos em que uma minoria de privilegiados reinava sobre uma maioria de não privilegiados. No ano passado [1976], ultrapassamos os quatro bilhões. Alguém se perguntou a que tipo de sociedade este crescimento conduzia, e que tipo de desenvolvimento trouxe com ela? Resposta: multiplicou a massa dos não privilegiados. É que tentamos fazer caber essas novas multidões, esse fervilhar sideral de caranguejos, no mesmo recipiente que foi fabricado para conter quatro ou dez vezes menos caranguejos. Mas, por favor! É a vasilha que tem de ser mudada. Dizendo de outra maneira, têm de serem mudados os valores da sociedade, ou, para ser mais objetivo, o uso que se faz da população mundial (ROSSELLINI, 1992, p.3-4).

E hoje? Este cenário mudou? Somos mais de sete bilhões de habitantes! Para o diretor, falta para todos eles uma informação educativa em contraponto ao sensacionalismo e manipulação dos meios de comunicação. Rossellini acredita que "(...) temos que ser capazes de olhar de frente, enfrentar, observando a coisa como é, tendo a coragem de pôr todos os dados na mesa, fazer um diagnóstico e buscar os meios mais inteligentes de resolver os problemas" (ROSSELLINI, 1992, p.4). Um destes meios seria através de seus filmes? A resposta a esta questão é dada pelo italiano em sequência: "É um procedimento global. Para mim, é também um procedimento estreitamente ligado à minha vida profissional: aquele que me leva, há 15 anos, a tentar promover um estilo de informação educativa" (ROSSELLINI, 1992, p.4).

Talvez seja por estas razões que Roberto Rossellini não se considerava o cinema seu ofício, ele nutria pretensões maiores para seus feitos, algo mais filosofal, como a contemplação das estrelas do conhecimento. Sobre a humanidade, ele afirma: "Pensamos que somo positivistas e racionais. Não é nada disso. Nunca fomos tão governados pela ignorância e pelo recurso ao mágico" (ROSSELLINI, 1992, p.18). E exclui-se, esclarecendo: 
Já é tempo de esclarecer um equívoco fundamental a meu respeito e vou fazê-lo: eu não sou um cineasta. Mesmo tendo nesse setor uma espécie de habilidade, o cinema não é meu ofício. 0 meu ofício é necessário aprender cotidianamente, e sua descrição nunca será exaustiva: o ofício de ser um homem. E o que vem a ser um homem? É um ser ereto que se ergue na ponta dos pés para ver o universo. Talvez minha paixão, e minha loucura, seja compreender, cada dia, um pouco mais (ROSSELLINI, 1992, p.10-11).

É notável a preocupação do diretor em um novo proposito para a mídia, bem como para a humanidade, além dos confins da ignorância e da desinformação. Rossellini ainda alega em biografia que a inteligência, enquanto virtude, é constantemente substituída pela astúcia, fato este que o preocupa. Ele problematiza questões como o conhecimento, que cresce exponencialmente, sem que a população se aproprie dele e de seu potencial libertador: "Em outros temos, nasciam um descobridor a cada três séculos. Agora, aparece um a cada três anos. E que êxtase diante desse desenvolvimento exponencial da população e uma inaptidão geral para encarar a verdade de frente" (ROSSELLINI, 1992, p.18).

Ele conclui com uma dura afirmação: "E aqui estamos nós, cada vez mais confusos, extraviados, perdidos!" (ROSSELLINI, 1992, p.19). Este trecho de sua autobiografia data de 07 de março de 1977, mas facilmente poderíamos transpor esta problemática para a atualidade. Vivemos em uma era de muita informação, mas pouca formação, com uma mídia televisiva impregnada pelo sensacionalismo.

Talvez a sociedade do espetáculo tão criticada por Rossellini nunca se findará. 0 que vem ocorrendo é uma progressiva regressão: "Os homens da Idade Média tinham um saber reduzido, mas o campo de pesquisa era então muito estreito. Já nós sabemos um pouco mais, porém nosso horizonte é incomensuravelmente mais vasto. Proporcionalmente, regredimos" (ROSSELLINI, 1992, p.19). Esta regressão é, em parte, relacionada pelo diretor aos meios de comunicação:

Os meios de comunicação que, em princípio, deveriam dissipar a escuridão, nada mais fazem do que difundir a ignorância à força de simplificações redutoras e de esquemas preparados de antemão. (...) As mídias são grandemente responsáveis pela situação de angústia e de 
confusão em que nos encontramos. Longe de desenvolver o conhecimento, implantam um estado de não relação entre o público e a realidade. 0 que é mais perigoso, é que proporcionam a ilusão de participar dos problemas, com seu discurso vagamente sociológico. (...) Ao invés de servir de médico parteiro para a humanidade, ajudando-a a nascer finalmente para o conhecimento, a mídia faz exatamente o contrário. É a mídia do anticoncepcional e do aborto. Mídia da morte do espírito (ROSSELLINI, 1992, p.19-20).

Essa ferrenha critica traz fortes alegações. Mídia da morte do espírito! Como o próprio diretor afirmou, já é tempo de fazer algo melhor! Rossellini mesmo proclamou: "Tento sempre fazer com que minhas análises sejam científicas, e estas palavras nada têm de polêmico" (ROSSELLINI, 1992, p.11). Torna-se claro o posicionamento do italiano que defende, irrefutavelmente, a objetividade e a cientificidade da sua escrita fílmica da história, além de suas ideologias políticas, não partidárias como ele próprio esclarece quando se refere à sociedade e sua condição:

É um problema essencialmente político. Deixando claro que a palavra é aqui empregada em seu sentido amplo, não em sua acepção partidária. Os partidos sempre nos aprisionam em um esquema, um discurso, uma aparência - um espetáculo - e aqui se trata de uma operação da liberdade total do homem, para a comunhão dos quatro bilhões de cérebros que povoa este planeta (ROSSELLINI, 1992, p.15).

Para superar a "sociedade do espetáculo" o diretor defende a promoção da cultura, que define como: “(...) o conjunto de produções de uma sociedade culminando em um pensamento" (ROSSELLINI, 1992, p.20). Para ele não há pensamento, nem tão pouco inteligência, apenas exercícios intelectuais absolutamente inúteis, limitadas apenas a repetições automáticas de estereótipos. Rossellini acredita que a inteligência se diferencia da em significação da mera astúcia:

A verdadeira inteligência é a capacidade de ler alguma coisa e compreendê-la no sentido etimológico da palavra 'prender com'; Claudel dizia que conhecer é 'co-nascer'. A astúcia é exatamente o contrário: é a escória da inteligência; é aviltar a faculdade mais nobre do homem 
e transformá-lo no autor de embustes, levá-lo a enganar, trapacear, recuperar (ROSSELLINI, 1992, p.21).

Trapacear e enganar são ações que colaboram para a construção do que o diretor acredita serem “(...) sistemas de tipo vertical onde as diferenciações hierárquicas são cada vez mais profundas, e o horizonte das pessoas cada vez mais estreito" (ROSSELLINI, 1992, p.23). Esta discrepância corrobora para promoção da desigualdade e, neste contexto, Rossellini faz mais uma crítica sobre como os trabalhadores são afetadas por este abismo social:

Como ousamos, por exemplo, correr atrás da dignidade do trabalhador, se o insultamos sem cessar? Como podemos falar em justiça social, se limitamos o conceito de homem a noções herdadas do passado, se continuamos a considerá-lo como sendo destinado ao trabalho e à dependência, recebendo seu salário como uma esmola? Tudo o que se conseguirá, será fazer com que o salário seja um pouco mais alto, a corrente um pouco mais dourada. Não me parece uma grande mudança. Na verdade, é um círculo vicioso, abominavelmente repressivo e reacionário. Para rompê-lo, seria necessário ousar contemplar o homem pelo que é (ROSSELLINI, 1992, p.24).

Mas o que, de fato, seria contemplar o ser humano pelo que é? Ainda sobre a questão do conhecimento, Rossellini lamenta: "Infelizmente, nós que possuímos especialistas em tudo, não temos especialistas em ser humano!" (ROSSELLINI, 1992, p.24). 0 diretor acredita que se faz necessário abrir espaço em meio às ocupações cotidianas para o exercício de aprender, uma vez que "(...) o conhecimento é como a água. Com sede, podemos beber uma jarra inteira. Do contrário, é um suplício" (ROSSELLINI, 1992, p.26). 0 grande acúmulo de conhecimentos na efemeridade da contemporaneidade, torna impossível ter contato com às páginas de todos os livros escritos de cada assunto existente, mas, na imagem, Rossellini acredita estar a grande dádiva, o potencial didático das mídias audiovisuais:

(...) Dispomos de técnicas extraordinárias para condensar através da imagem tudo o que foi pensado, refutado, demonstrado, desde que o homem existe, e para pôr tudo isto à disposição de todos, da maneira 
mais facilmente assimilável. (...) A imagem deveria permitir a criação de uma linguagem suficientemente rica para que pudesse satisfazer a todos, e que seria a linguagem da inteligência humana, isto é, de todas as formas possíveis de inteligência (ROSSELLINI, 1992, p.26).

Com o intuito de fornecer algo a mais de realidade, Roberto Rossellini buscou diferenciar-se do antigo realismo, trazendo o espectador de volta ao mundo concreto e histórico. Entre 1964 e 1973, o diretor se dedicou a um período televisivo com o intuito declaradamente pedagógico, assumindo um papel educativo para seus filmes. Neste intervalo produziu nove obras que tinha forte caráter enciclopédico, humanista e didático, com o objetivo de retratar o desenvolvimento científico da humanidade, através de retratos biográficos de grandes personalidades da história do pensamento.

Entre seus trabalhos televisivos temos: L'Età Del Ferro (1964), La Lotta Dell'Uomo Per La Sua Sopravvivenza (1967-69), Atti Degli Apostoli (na Tv: O Acto dos Apóstolos, 1968), La Prise de Pouvoir Par Louis XIV (1965), Socrate (1970), Blaise Pascal (1971), Agostinho d'Iponna (1972), L'Età di Cosimo de Medici (1972) e Cartesius (1973). Durante este período, Rossellini incorporou a linguagem cinematográfica para a televisão, num enfoque educacional, conservando muito do estilo que este utilizava em seus filmes.

Apresentaremos nesse artigo o resultado da análise fílmica feita com as transcrições de diálogos do filme Sócrates, imagens e fotogramas das cenas escolhidas, segundo a perspectiva de análise proposta por Jacques Aumont e Michel Marie (2004) em A Análise do Filme. Relacionaremos esses trechos com artigos científicos já publicados sobre o filósofo, sua história e pensamentos, incluindo aquelas escritas por seus discípulos como Platão. Buscou-se assim, mostrar os limites e as possibilidades de se referir sobre as relações do discurso fílmico, científico e histórico bem como evidenciar que o uso do cinema pode contribuir para a compreensão de conceitos filosóficos, mesmo advindos de uma representação, no caso a feita através da linguagem cinematográfica. 


\section{Sócrates: Conhecimento E Relações Familiares}

Sócrates (1970), objeto de interesse deste artigo, é o primeiro dos quatro filmes dedicados a filósofos, ao qual seguem Blaise Pascal (1971), Agostino d'lppona (1972) e Cartesius (1973). Esse primeiro filme foi realizado em 1970 na Espanha, numa coprodução RAI-ORTF, e apresentado na televisão italiana em 1971, com a duração de 120 minutos e uma estimativa de 6,2 milhões de espectadores. Fausto Cruchinho (2007) em A Televisão de Roberto Rossellini, descreve os acontecimentos principais do filme:

Soldados espartanos destroem o muro de Atenas; Teofrasto comenta a ocupação de Atenas por Esparta, acusando Alcibíades; desejo o regresso de Alcibíades e o fim da tirania dos Trinta e de Crítias; Sócrates e Críton são atacados na rua pelos atenienses; Meleto critica a justiça de Sócrates; atenienses crucificados pelos tiranos de Esparta; Sócrates lamenta a falta de razão nas decisões dos tiranos; "a justiça é o maior dos bens"; na loucura e o crime mostram a ignorância do bem"; Sócrates é proibido de falar aos jovens; Sócrates é preso pelos tiranos; Crítias é assassinado pelos espartanos; a democracia é restabelecida em Atenas; Sócrates encontra Aristófanes; Sócrates ridiculariza a democracia; Sócrates assiste a uma cerimónia pagã; "a morte é uma libertação"; Meleto acusa Sócrates de corromper a juventude e pede a sua morte; Sócrates encontra Hípias e falam sobre a beleza; Sócrates conta uma fábula egípcia em que o que é escrito é imagem do discurso e serve a memória, podendo ser esquecido, enquanto que o que é dito é direto e usa a razão; Sócrates encontra Eutífrone que acusa o próprio pai de homicida; Lísias é chamado para defender Sócrates; Sócrates decide defender-se sozinho, tentando fazer triunfar a verdade; eleição dos juízes de Sócrates; Sócrates é acusado por Meleto, Aflito e Licone de não crer nos deuses de Atenas, de propor novos deuses e de corromper a juventude; Sócrates diz-se sábio, consciente da sua ignorância, crente num deus e no fim da razão; Sócrates é condenado e defende-se criticando a democracia e retribui o desprezo que Atenas tem por ele; Sócrates recusa o exílio e diz-se um instrumento dos deuses; Críton prepara a fuga de Sócrates para Tessália; Sócrates condena-se à morte para não cometer uma injustiça combatendo uma injustiça; «a alma é imortal porque faz viver o corpo e não o mata»; Xântipe faz o elogio de Sócrates; Sócrates bebe a cicuta e morre em paz (CRUCHINHO, 2007, p.327). 
Durante os créditos iniciais, prevalece na atmosfera uma música instrumental semelhante a tambores que perdura por aproximadamente um minuto. Este som lembra o de tambores, alimentando o clima de tensão comum à do suspense que antecede um resultado, sentença ou grande revelação.

A primeira cena é externa e diurna (esterno giorno) como são classificadas a maioria na narrativa. Ela se destina a caracterização e contextualização temporal e histórica da cidade de Atenas, derrotada na guerra do Peloponeso perante Esparta (431 a.C. a 404 a.C.). Em relação à profundidade, a cena foi filmada em plano aberto (campo lungo). Um soldado espartano proclama de forma enfática:

Hoje, sexto dia do mês Mounikhion² do primeiro ano da sexagésima quarta Olimpíada, por ordem de Lisandro de Esparta, nosso valente comandante com nossa presença e com a vossa, valorosos confederados segundo as condições de rendição que impusemos à cidade de Atenas, daremos agora início à demolição das muralhas (ROSSELLINI, 1970, $1 \min 43 \mathrm{~s}$ a $2 \min 35 \mathrm{~s})$.

Todos se levantam. A muralha, símbolo que outrora ofereça refúgio e segurança, cai e os atenienses pesarosos assistem, temendo que a derrota sofrida faça com a democracia também se esfacele (imagem 1). Hermes, Teofrasto e outros mercadores reúnem-se, cercados de comidas e bebidas, debruçados sobre confortáveis almofadas, especulando sobre o fim da hegemonia ateniense. Dos filmes televisivos do diretor italiano, Sócrates é aquele que mais demora para surgir a tela seu protagonista.

Lisandro e seus soldados celebram. Mulheres atenienses tocam seus instrumentos, lira e flauta, entoam uma triste melodia que perde na atmosfera sonora para o som dos soldados eufóricos e dos destroços da muralha. A pesquisadora em filosofia Marly Meinberg em Sócrates: A Individualidade na Grécia (2003) descreve os conflitos mencionados na narrativa e seus impactos sobre Atenas:

\footnotetext{
2 Mounikhion é o décimo mês (ou décimo primeiro quando o ano tinha 13) do antigo calendário grego em vigor na região de Atenas, durou 29 dias entre aproximadamente 23 de março e 21 de maio do nosso calendário atual1. Seu nome vem da palavra grega (Movvıхı́́v / Mounikhiốn) para a festa dos Mounikies em homenagem a Artêmis.
} 


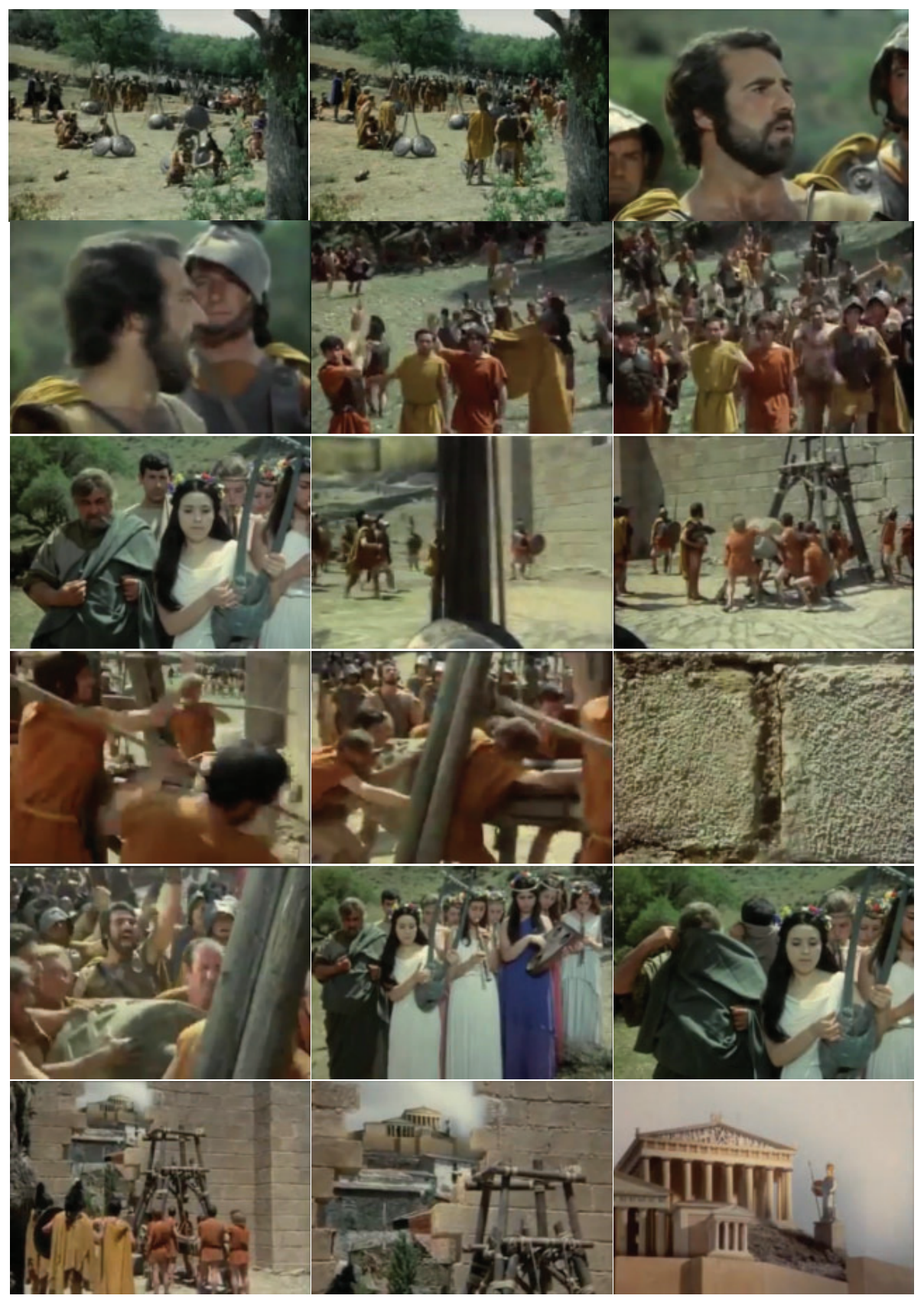

Imagem 1: Fotogramas da cena que ilustra a queda da muralha ateniense e marca a vitória dos Espartanos.

Revista Páginas de Filosofia, v. 9, n. 2, p. 69-107, jul.-dez. 2020 
Em 431 a. C, quando Atenas estava no auge do seu poderio inicia-se o conflito contra Esparta que ameaçava seu império. Contrariamente ao que Péricles acreditava, esta guerra, chamada de Peloponeso iria revelar-se longa e assassina. Estendeu-se rapidamente, pelo jogo das alianças, a todo o Egeu e até mesmo ao ocidente, em particular à Sicília. No verão de 405 a. C terminou o domínio que Atenas havia exercido durante três quartos de século sobre o mundo Egeu (MEINBERG, 2003, p.03).

Por uma brecha no muro, ao alto vai surgindo uma esplêndida imagem da Acrópole, uma cidadela no ápice de uma montanha repleta de construções antigas, como o templo Partenon, suas colunas e estátua da deusa da sabedoria, merecedora do enquadramento desta cena. Nas palavras de Rossellini, em seu roteiro:

De repente todos se calam: os espartanos, imóveis e em silêncio, encontram-se agora diante do espetáculo da Acrópole que se avista através da brecha aberta nas paredes, como uma esplêndida imagem sagrada profanada (panorâmica para subir e ampliar para a Acrópole). 0 oficial, rodeado por seus homens, observa a cena em silêncio, visivelmente perturbado (leve zoom). 0 velho ateniense fica encoberto enquanto as meninas continuam a tocar a melodia fúnebre (carruagem acompanhada no meio campo). 0 grupo de outros espectadores não vibra mais (primeiro plano do meio), enquanto, ao fundo, a Acrópole se apresenta como uma visão alucinante (zoom in) (CRESCI, 1972, p.26).

Descrevendo cenas e comentando-as, Peter Brunette (1987), também debruça seu olhar sobre a obra Sócrates (1970), dando ênfase a passagem inicial de sua narrativa. Observemos a descrição feita por ele da filmagem do cenário e suas respectivas imagens, realizando uma comparação estilística com outra obra de Rossellini, A Ascensão ao Poder de Luís XIV (1965) (La Prise de Pouvoir Par Louis XIV):

O filme começa, de fato, com a destruição dos muros de Atenas, como os espartanos vitoriosos olham com espanto para a acrópole, a preciosa civilização que acabaram de derrotar. Como de costume, estamos em um ponto de virada importante na civilização ocidental, um ponto de transição, e ninguém sabe o que vai acontecer a seguir. A filmagem fosca do Parthenon e outros edifícios gregos não são muito boas (embora sejam mais convincentes na tela pequena), parece claro que esta não foi feita 
por designers: "Sócrates foi feito com um sistema de processamento que temos desenvolvido. Fiz isso na Espanha, com um cinegrafista espanhol, que não estava acostumado com esse tipo de coisa, por isso o resultado não foi muito satisfatório, mas eu não me incomodo. Eu tinha um monte de cenas com o mesmo tipo de processamento de filmagens usadas em Louis XIV, como a construção de Versalhes e, no início, o palácio do Louvre"³ (BRUNETTE, 1987, p.298-299, tradução da autora).

Podemos observar também o detalhe de Rossellini na escolha dos figurinos e dos personagens, o que favorece o tom histórico da narrativa. Sócrates aparece na narrativa, pela primeira vez, na cena referente a distribuição de comida pelos Espartanos em Atenas, após a invasão e domínio da cidade, cena sete do roteiro, intitulada Ruas de Atenas (Strade di Atene). 0 filósofo é criticado por atenienses por ter sido mentor de Alcibíades e Crítias e se defende:

O que você quer! Por acaso deveria ficar nervoso se levasse um coice de uma mula? É difícil levar um asno perante um tribunal. Se você tivesse me escutado todos esses anos que trato de despertar consciência saberia que existe um único bem: o conhecimento; e um só mal: a presunção do saber. É bom ter ideias sobre o que se conhece, mas vocês atenienses, só tem opiniões. Opiniões sobre tudo. Por orgulho, por deficiência, falam somente de coisas que não conhecem, ou que conhecem mais ou menos (ROSSELLINI, 1970, 12min53s a 14min28s).

Roberto Rossellini é um homem de dualidades e neste trecho temos a menção do conhecimento e da astúcia, colocados em posição de adversidade. 0 zoom vai da multidão à Sócrates que, após ser chamado

\footnotetext{
3 Texto original em inglês: "The film opens, in fact, with the destruction of the walls of Athens, as the victorious Spartans look up in amazement at the acropolis, the jewel of the civilization they have just defeated. As usual, we are at an important turning point in Western civilization, a point of transition, and nobody knows what will happen next. The matte shots of the Parthenon and other Greek buildings are not very good (though they are more convincing on the small screen), but it seems clear this was not by design: Socrates was made with a processing system that we have developed. I did it in Spain with a Spanish cameraman, who was not at all used to those kinds of things, so the result is not very satisfactory, but I don't mind. I had a lot of the same kind of processing shots in Louis XIV, the building of Versailles and, in the beginning, the Louvre palace. But there I had a cameraman who was more capable than the other one".
}

Revista Páginas de Filosofia, v. 9, n. 2, p. 69-107, jul.-dez. 2020 
de imbecil por Crítion, o responde de forma pacífica: "Consideremos todas as opiniões, ainda aquelas que desaprovamos. 0 que me importa é concordar comigo mesmo, e tratar de nunca fazer o contrário do que penso". Um dos agressores intervém desafiadoramente: "E o que você pensa? Que diabos sabe mais do que os outros?". Sócrates responde com sua frase célebre: "O que sei que os outros não sabem? É que sei que nada sei". Os fotogramas desta cena podem ser observados na imagem 2, abaixo:

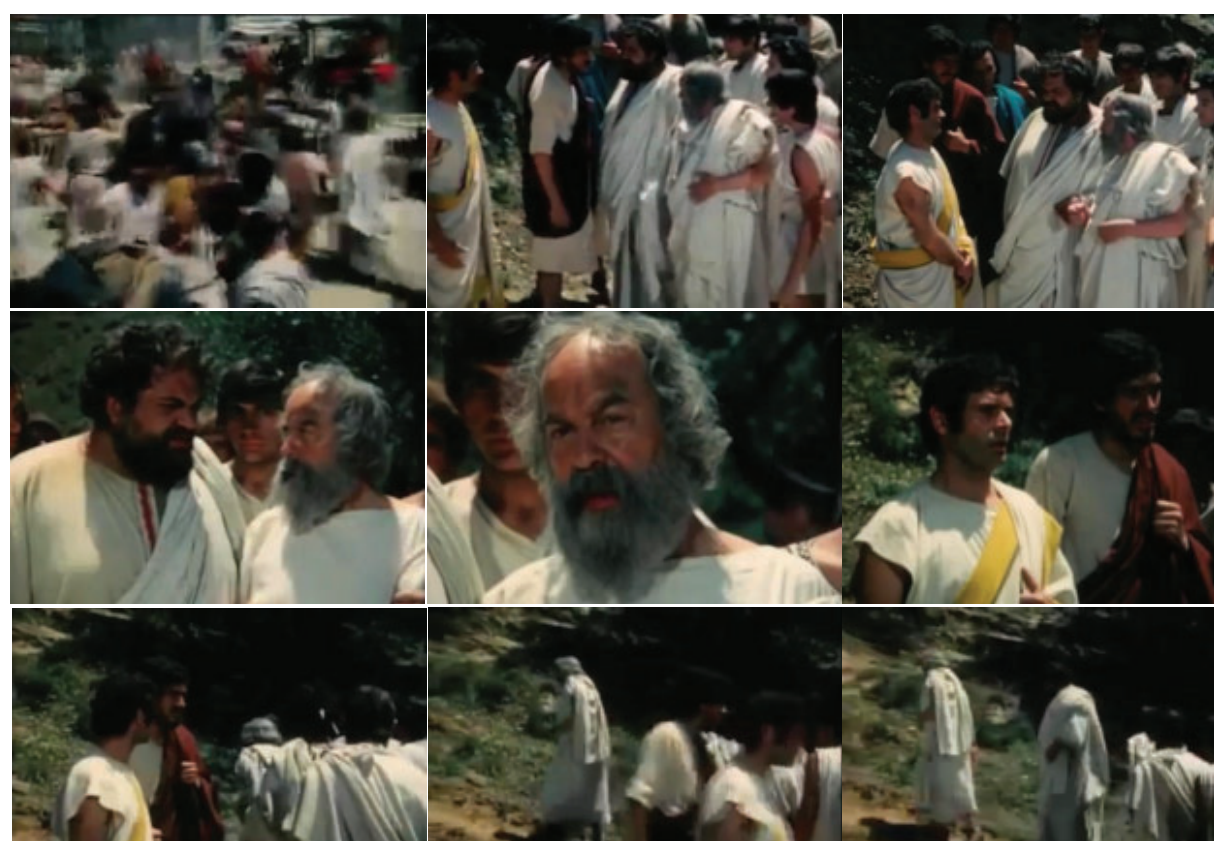

Imagem 2: Fotogramas da cena de distribuição de comida pelos Espartanos em Atenas, após a invasão e domínio da cidade.

Roberto Rossellini deu vida à Socrates, enfatizando seu papel enquanto filósofo e orador, mas também preocupou-se em incorporar na narrativa como eram tecidas suas relações familiares. 0 diretor procurava retratar seus personagens em sua humanidade. A próxima 
cena, interna e diurna (interno giorno), escolhida para análise é a de uma discussão entre Sócrates e sua esposa Xântipe. 0 enquadramento dá enfoque a mulher, acompanhando-a.

Xântipe se preocupa por ele ter ficado dois dias sem retornar à casa, mostrando que o filósofo, absorto em seus pensamentos, chega a esquecer de suas responsabilidades como patrono de sua família:

Xântipe: Dois dias! Dois dias de angústia! Espartanos por todos os lados, a cidade cheia de perigos e você só voltou para casa porque te deu fome! Não me importa que seus filhos estejam com fome! Tudo o que te interessa é tagarelar por aí com os pés na poeira! Estive sozinha por dois dias, dois dias sem comer nada! Por um acaso você acha que podemos comer suas palavras? (ROSSELLINI, 1970, 18min40s a $21 \mathrm{~min} 12 \mathrm{~s}$ ).

Sócrates tenta dialogar e é interrompido bruscamente por sua esposa que lhe diz: "Conheço seus discursos de cor!". O filósofo ainda insiste: "Mas como? Se nunca me deixe falar". Neste trecho podemos observar que na narrativa fílmica, Sócrates é uma figura de temperamento sereno e de oratória eloquente, mesmo nas situações mais triviais. 0 diálogo entre o casal continua, fervorosamente, e Xântipe afirma:

Você está entediando todo mundo com suas palavras. Ao invés de rir da suposta ignorância do povo, seria melhor cuidar de você mesmo. Olhe só para você! Tem até pulgas! Agora que fomos derrotados, finalmente não terá mais a desculpa de ir até a Assembleia e poderá ganhar o pão para sua família! Falar por falar! Pelo menos cobre daqueles que te escutam! Faça como Hípias, que cobra para ensinar os filhos dos ricos! São tão estúpidos que até te dariam dinheiro! (ROSSELLINI, 1970, $18 \min 40 \mathrm{~s}$ a $21 \mathrm{~min} 42 \mathrm{~s}$ ).

Na transcrição desta cena, podemos observar que Sócrates atribui um valor incomensurável e inestimável ao conhecimento. Já sua esposa, refletindo sobre a situação de pobreza em que via sua família, alega que o filósofo deveria cobrar por seus ensinamentos, como fazia Hípias. Estes acontecimentos podem ser observados nos fotogramas da imagem 3 , a seguir. 

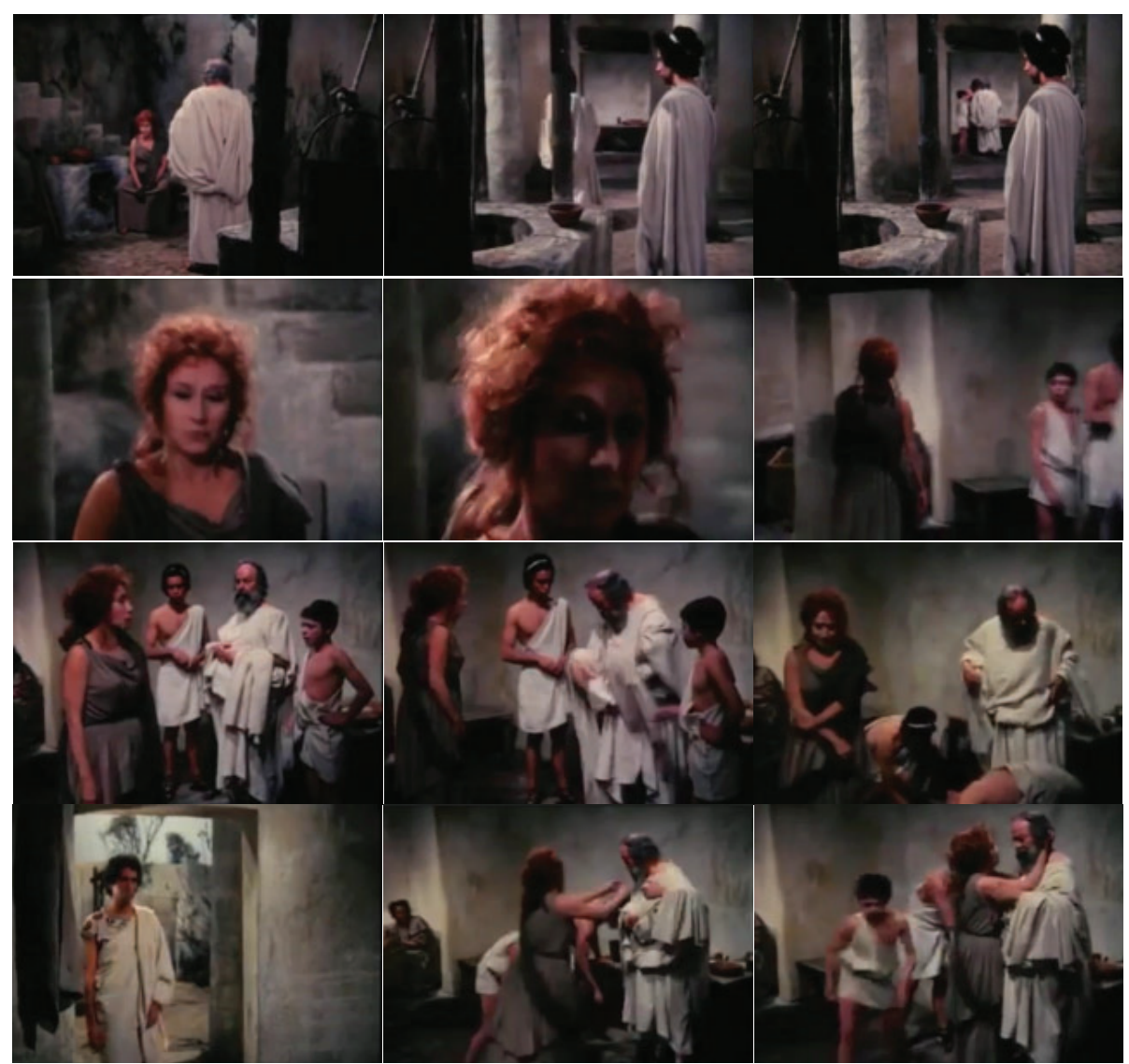

Imagem 3: Fotogramas da cena na qual Xântipe discute com Sócrates.

Sócrates lhe responde, fazendo outra alusão a sua frase icônica: "Mas eu não sei nada, Xântipe e este conhecimento não se vende". A mulher continua: "Eu te suplico Sócrates! Estamos quase na ruína, ódio por todos os lados. Tenha cuidado. Há anos que você faz inimigos e os golpes da injustiça chegam sem avisar!". Premonição ou advertência? O destino de Sócrates já estaria traçado?

\section{O HOMEM, A LENDA E O ORÁCULO:}

Ainda sobre os desdobramentos da derrota ateniense no conflito do Peloponeso, Sócrates conversa com o grupo que o segue sobre Crítias 
enquanto atravessa a cidade. Eles veem prisioneiros de guerra sendo torturados, amarrados em altas hastes de madeira, (legati ad alti pali infissi nel terreno) ao sol e em jejum, morrendo lentamente (imagem 4). Um dos seguidores do filósofo desabafa sobre a situação: "O que se pode fazer? Eles estão agonizando a dias e não se pode fazer nada para socorrê-los ou quem sabe aliviar seus sofrimentos ainda que seja em um golpe só!". A cena é externa e diurna (esterno giorno), filmada em plano americano com o enquadramento ao fundo (zoom all'indietro d'accompagnamento in piano americano).

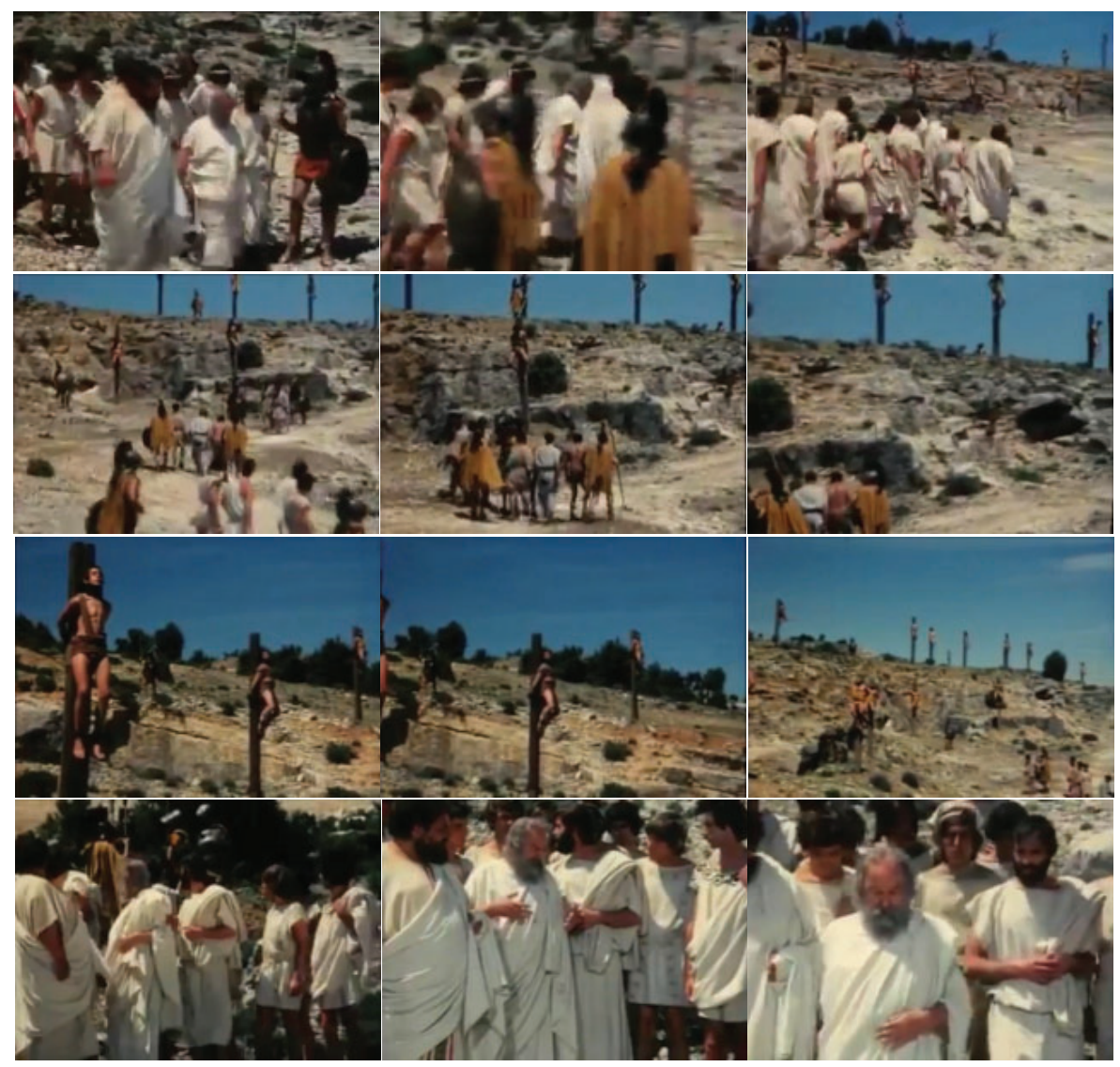

Imagem 4: Fotograma da cena que retrata Sócrates conversando com o grupo que o segue sobre Crítias, o domínio de Atenas e a tortura dos prisioneiros de guerra.

Revista Páginas de Filosofia, v. 9, n. 2, p. 69-107, jul.-dez. 2020 
Crítobulo mensura o tamanho da tragédia de seu povo e culpa, ainda que indiretamente, Sócrates: "Os tiranos já condenaram 1500 atenienses a tortura e ninguém se rebela. Crítias é o pior de todos. Crítias, Sócrates! Um de seus antigos discípulos".

Sócrates se defende dizendo que não considera seus antigos discípulos bons magistrados e argumenta: "Por quê! Por quê Alcibíades e Crítias não cultivaram a razão? Por quê não fizeram silêncio dentro de si para deixar a voz dos deuses lhe inspirarem? A medicina cura o corpo, a política deveria velar pelas almas".

Para o filósofo fica claro que o fazer político é algo que deve ser realizado com responsabilidade, num processo de auto reflexão. Ele conclui dizendo que a a política deveria ser a arte de ensinar a todos a justiça e não a arte da dominação. Esta cena da tortura dos soldados espartanos é a de maior violência na narrativa, mais do que a da própria condenação de Sócrates à cicuta. Citando, novamente, Marly Meinberg (2003) temos, em seu artigo, a menção ao domínio espartano, o governo dos Trinta e a situação crítica de Atenas, no pós-guerra. 0 destino de filósofos e oradores também é descrito, muitos condenados à morte ou exilados:

Depois da rendição definitiva de Atenas diante de Esparta, a cidade vencida e arruinada, foi dilacerada por uma guerra civil. 0 inimigo interno - o partido aristocrático - aproveitou das ruínas e da comoção da derrota para montar o governo tirânico chamado dos "Trinta", com o apoio do inimigo espartano. Os oradores democratas foram perseguidos, condenados à morte ou obrigados a tomar o caminho do exílio. Durante alguns meses as execuções se sucederam visando todos aqueles cidadãos ou estrangeiros, de quem se suspeitava de ligação com os democratas exilados. A partir destes, e contando com o apego dos cidadãos ao regime que há mais de meio século estava ligado à grandeza de Atenas, foi possível armar uma reação ao domínio de Esparta sobre o governo dos "Trinta", que termina em um acordo com os tiranos que previa a restauração da aliança e anistia a todos aqueles que não tinham participado de crimes (MEINBERG, 2003, p.03).

A narrativa prossegue e Sócrates, como é seu costume, junto com seus jovens discípulos, caminha ao longo do rio. A cena é externa e diurna (esterno giorno), como muitas das já citadas. Chegando perto de uma árvore frondosa, ele para. Assim como Rossellini explorou em seu roteiro a antítese entre ideias e opiniões, também o faz com o par loucura e crime, suscitados pela dinâmica do poder.

Revista Páginas de Filosofia, v. 9, n. 2, p. 69-107, jul.-dez. 2020 


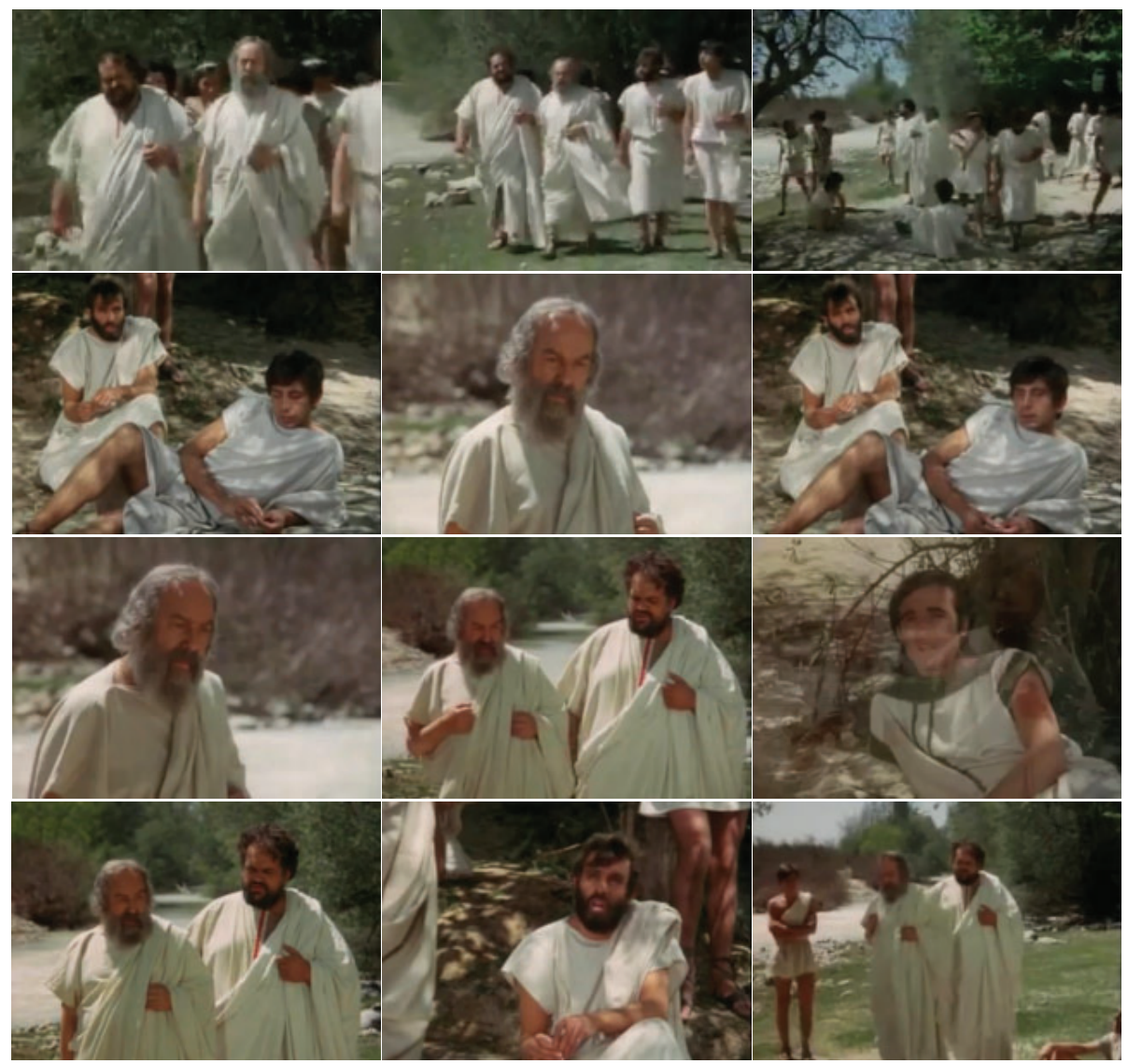

Imagem 5: Fotogramas da cena que mostra Sócrates dialogando com seu grupo sobre loucura e poder.

Estes conceitos por demais abstratos, Sócrates, com sua oratória, esmiúça de formal filosofal, após a indagação de Símias, acompanhado de Antístenes (imagem 5): "Não faz muito tempo, referiu-se a Crítias e os outros tiranos, usando a palavra 'loucura', mas nossos tiranos não estão loucos, Sócrates, são criminosos”. E o diálogo prossegue:

Sócrates: Mas a mesma coisa! Você conhece a canção que diz que o maior bem é a saúde em primeiro lugar, seguida pela beleza e pela riqueza?

Símias: Sim, conheço. 
Sócrates: Bem, esta canção mente. A maior felicidade é ser justo. Tão grande é este bem, aqueles que o fazem mal são loucos. Por isso usei a palavra loucura.

Antístenes: É uma loucura da qual eles lucram, Sócrates.

Sócrates: Qual é o lucro? A riqueza? O domínio sobre outros homens? Mas quando perderem este poder, o que será deles? A recordação dos crimes que cometeram e o que mais? A ignorância do bem? Uma ignorância que só as ilusões do poder os impedem de enxergar e que outra razão pode haver para seus crimes, senão tal ignorância que os mantém em um estado de perpétua ansiedade. Na verdade, os poderosos têm a força e a exercem porque são em essência fracos e está fraqueza vem do medo que os domina. Acreditam sempre que estão rodeados de inimigos. Não é por acaso o que chamamos de loucura? (ROSSELLINI, $1970,24 \min 17 \mathrm{~s}$ a $26 \min 49 \mathrm{~s}$ ).

Não somente sobre a temática do poder e da loucura, mas em tantos outros, Sócrates profere seus ensinamentos ao ar livre. Assim como fez Símias e Antístenes, Fédon participa da conversa, indagando: "Então a virtude é o conhecimento do próprio bem?". Sócrates confirma: "O conhecimento e a prática". Antístenes ainda insiste, argumentando novamente para sanar as dúvidas que lhe foram suscitadas:

Antístenes: Então para governar a cidade sem ser nocivo para si mesmo, um poderoso deve possuir a virtude?

Sócrates: Sim, porque se é um homem de valor, servirá de exemplo a todos. Para sobreviver, os Estados não necessitam de arsenais ou mesmo de impérios. Se tiverem valor e possuírem a virtude, os cidadãos irão dar a vida para defendê-los (ROSSELLINI, 1970, 24min17s a $26 \mathrm{~min} 49 \mathrm{~s}$ ).

Por atitudes como esta, de proferir suas ideologias e ensinamentos, Sócrates é convocado a prestar esclarecimentos perante a Assembleia. Platão, seu discípulo, escreve sobre as reflexões internas de seu mentor, que encarava seus feitos como uma missão que lhe foi designada por alguma força superior:

Ele se diz investido de uma missão divina que o leva a comportar-se como se comporta, a indagar, a questionar, a espicaçar, a acordar, missão que, em caso algum, pode abandonar. Trata-se de uma missão conscientemente aceite, de viver filosofando, examinando-me a mim próprio e 
aos outros e enquanto tiver um sopro de vida, enquanto me restar um pouco de energia, não deixarei de filosofar (PLATÃo, 1972, 84-85).

Inspirado por esta missão e repleto de questionamentos, Sócrates encontra Calicles, homem da lei, em Tholos. Esta cena é interna e diurna (interno giorno), filmada em sua maioria, em médio plano (médio primo piano). 0 filósofo argumenta de forma pacífica que seus feitos possuem intenção meramente pedagógica. Sobre este aspecto, Luiz Fernando Bandeira de Melo afirma que:

Para Sócrates pouco progresso mental se obtinha do simples fato de ministrar conhecimentos com os métodos populares que os sofistas proporcionavam - que almejavam disseminar informações por meio de prestações formais - uma vez que o método de conversação socrática trazia mais benefícios de aprendizagem, e tinha como objetivo o poder de pensar. 0 seu alvo era formar jovens capazes de tirar conclusões corretas, e formular a verdade por si mesmos, em vez de dar-lhes conclusões já. Portanto, para Sócrates, a educação tinha por objetivo imediato o desenvolvimento da capacidade de pensar, não apenas ministrar conhecimentos, processo educacional que pode ser encontrado nos momentos atuais da moderna pedagogia (MELO, 2006, p.02, grifo do autor).

Na Assembleia, Calicles é direto: "Venha e se aproxime Sócrates. Nós o acusamos de violar a lei que proíbe o ensino das técnicas da oratória". O filósofo se defende, reiterando seu compromisso em seguir as leis de Atenas e através de outras perguntas, provoca indagações em Calicles. Sócrates usa outra antítese, explorando as diferenças entre "a arte de convencer com astúcia" e "a busca natural da verdade":

Sócrates: Mas eu estou decidido a obedecer às leis. Tanto esta como as outras. Agora veja bem, para cumpri-la melhor quem sabe poderia me explicar o que entendes por "técnicas de oratória". Quer dizer que ensino a arte de convencer com astúcias, ou o bem, a busca natural pela verdade?

Calicles: Para que me pergunta, se você já sabe a resposta?

Sócrates: Vocês estão enganados. Se eu te faço a pergunta é que busco a verdade, para você e para mim. De fato, se você acredita que eu, Sócrates, uso a língua grega para garantir algum tipo de poder sobre os homens. Neste caso, aprovaria sua proibição, mas talvez o que você não 
saiba é que me limito a fazer os outros a pensar através de perguntas, e que o diálogo que daí surge não tem outro objetivo senão de criar a compreensão.

Calicles: Pouco importa o que eu sei. Limitamo-nos a te dar uma ordem bem clara: Não volte a dirigir a palavra aos jovens (ROSSELLINI, 1970, $27 \mathrm{~min} 30 \mathrm{~s}$ a $29 \mathrm{~min} 21 \mathrm{~s}$ ).

Sócrates ainda insiste: "O que eu entendi é que querem me impedir de falar da justiça!”. A história já é conhecida: O ultimato de Calicles não surte efeito e Sócrates acaba sendo levado a julgamento pela mesma razão alegada pela Assembleia, a de corromper a juventude com sua oratória, ensinando-a a transgredir as leis e os costumes do povo ateniense. Apesar desta cena ser interna, a iluminação é bastante clara e a imagem nítida, na qual a câmera ora se aproxima, ora se afasta do protagonista. Na atmosfera sonora, voltam os sons instrumentais da abertura, semelhante aos de tambores:

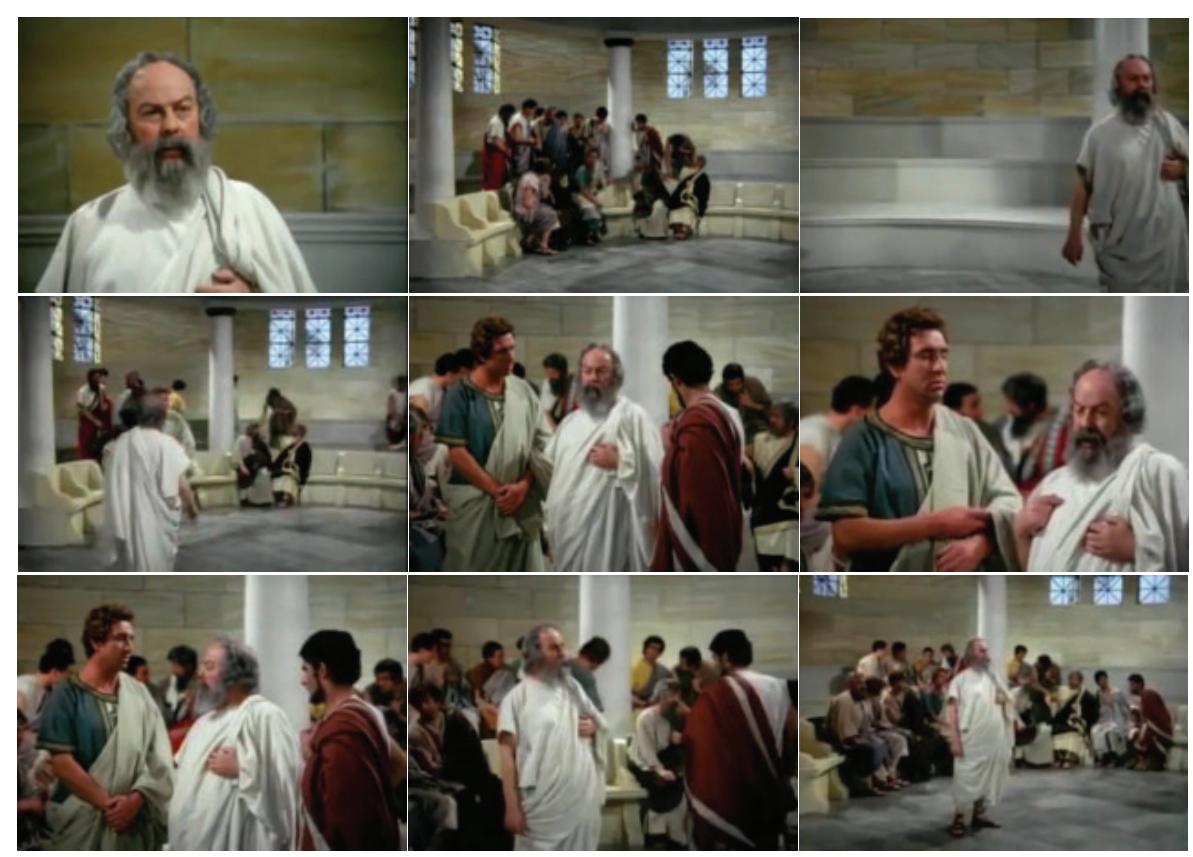

Imagem 6: Fotograma da cena na qual Sócrates vai ao encontro de Calicles, prestar esclarecimentos. 
Sócrates deixa claro sua decisão sobre as advertências que recebeu de Calicles, em seu diálogo com Hiperides sobre Critias. 0 últimato não surte efeito e a temática da loucura é retomada na narrativa:

Hiperides: Olhe a que ponto chegamos. Odeio estes tiranos com toda a minha alma.

Sócrates: Odeia, mas se apressa em obedecê-los porque tem medo. Eu não os odeio, mas não cumprirei as suas ordens. Vou voltar para minha casa.

Hiperides: Mas isso é uma loucura, Sócrates!

Sócrates: As vezes temos que saber ser loucos! (ROSSELLINI, 1970, $29 \mathrm{~min} 41 \mathrm{~s}$ a $30 \mathrm{~min} 36 \mathrm{~s})$.

Na continuidade do longa-metragem é mencionado que Critias morre em combate e é ofertado por seu sucessor anistia política a todos, mas as desavensas que mencionaremos a seguir, entre Sócrates e Meleto dificultam a situação do filósofo com a justiça ateniense. Em conversa com Anytos, Sócrates afirma ser leal a sua voz interior, uma das questões alegadas contra ele em sua condenação:

Anytos: Esqueci-me que você se acha o mestre da virtude.

Sócrates: Você está enganado. Só exerço o mesmo ofício que minha mãe. Ela era parteiram mas não são meninos o que trago ao mundo, mas a verdade e graças a uma arte que eu e alguns deuses conhecemos.

Anytos: Estão vendo? Traz-nos novos deuses.

Sócrates: Não. Eu simplesmente creio em uma voz interior, assim como vocês acreditam nos presságios das aves.

Anytos: Os atenienses são filhos da Terra. Se o destino os golpeou, é porque charlatães como você afastou-os de suas tradições. Só por isso! (ROSSELLINI, 1970, 40min45s a 43min09s).

Sócrate foi acusado de incentivar os jovens a acreditar em novos deuses, desrespeitando as tradições atenienses. Sobre estas questões, se inicia a discussão com Meleto, que ocorre enquanto Sócrates, seguido por alguns concidadãos, caminha pelas ruas de Atenas falando de forma reflexiva:

Meleto: Alcibíades foi seu aluno favorito, ele que nos trouxe a ruína. Alcibíades, mutilador das estátuas de Hermes, aquele a quem ensinastes o desprezo pela tradição. 
Sócrates: Não. Eu simplesmente quis ensinar-lhe que tem que saber reconhecer o novo que a vida nos entrega continuamente.

Meleto: Em outras palavras, querias dizer sua traição e nossa ruína! (ROSSELLINI, 1970, 43min24s a $47 \mathrm{~min} 53 \mathrm{~s}$ ).

Outros cidadãos também se manifestam na discussão sobre quem seriam os mais adequados para se encarregaram dos assuntos da cidade bem como de sua administração. Meleto intervém com irreverência, prosseguindo o diálogo:

Meleto: Tome cuidado! Falas como esses filósofos estrangeiros que nos infestam com suas doutrinas. E lembre-se que Protágoras foi condenado. Sócrates: É triste ver como os tribunais de Atenas se colocam a serviço da inveja e do medo.

Meleto: Você fala de justiça, enquanto os outros falam em pátria. Onde estaria, então, sua pátriam Sócrates?

Sócrates: Minha pátria é Atenas. Isso eu demonstrei no campo de batalha. Mas também sigo a crença de que a terra é imensa, com muitos povos espalhados em torno do mar, como rãs em um lago. A sabedoria não é só ateniense, a força não é só espartana, nem a prudência somente corintia. Estas virtudes os outros povos também possuem. Sou ateniense, mas também sou um homem, como todos da terra.

Meleto: Cuidado com o que diz. Poderia ser acusado de ofender a nossos deuses e de depreciar nossas tradições.

Sócrates: As trdiações só têm sentido se podemos apreciar o seu significado. Há que se desconfiar dos hábitos. Sem ir mais longe, os chefes de nossa cidade, escolhidos, como de costume, pelo azar, quase todos ignorantes com a presunção do saber, podem ser presa fácil do primeiro que apareça e cometer injustiças. Isto nos permite cotidianamente medir a força da calúnia (ROSSELLINI, 1970, 43min24s a 47 min53s).

Da coleção "Os Filósofos", dirigida por Roberto Rossellini, o filme destinado a Sócrates é aquele com a maior contextualização histórica, mostrando a guerra entre Atenas e Esparta como pano de fundo dos desdobramentos da narrativa. A cinebiografia esta inserida em uma dualidade e impregnado por ela em seus diálogos carregados de antíteses. As dualidades do trecho transcrito acima são entre justiça e pátria, hábitos e tradições. 


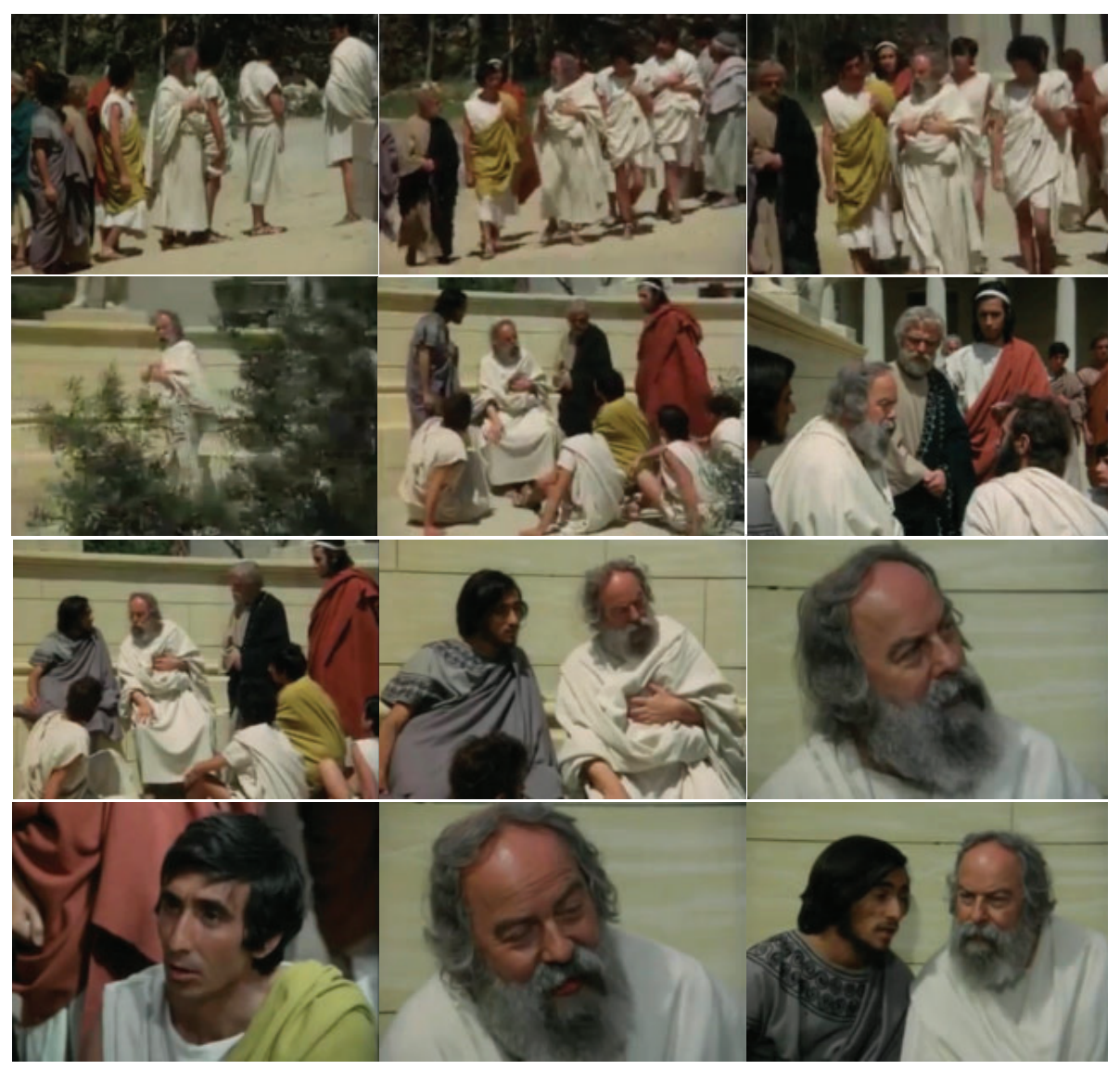

Imagem 7: Fotogramas da cena na qual Meleto se indispõe com Sócrates, que dialoga sobre poder e política para seus seguidores.

Sócrates e Meleto enquadrados em primeiro plano (primo piano) em mais uma cena externa e diurna (esterno giorno). 0 filósofo não teme a morte e em outro momento da narrativa afirma que talvez esta seja doce e nos aproxime definitavamente da verdade. Em conversa com Críton, Sócrates confessa: "Eu sigo crendo que a morte é uma libertação. Se não posso ter certeza enquanto habito meu corpo das duas uma: ou me está vedado o conhecimento ou terei este conhecimento através da morte. E sabes que sou muito curioso". 


\section{Condenação, Sacrifício e Paixão}

A saga que termina com a condenação de Sócrates se inicia e será palco dos próximos cinquenta minutos do longa-metragem. As acusações contra o filósofo, feitas por Meleto, são colocadas no pórtico do Arconte. Ele é acusado, como já mencionamos, de não acreditar nos deuses, pregar novas crenças para Atenas e corromper a juventude. É exigida a pena de morte. Sócretes encontra Eutífron e explica as razões da denúncia que sofreu:

Eutífron: Por que veio Sócrates? Agora você também frequenta o pórtico de Arconte? Eu estou aqui porque acabei de abrir um processo diante do Arconte rei.

Sócrates: Eu vim porque eles querem me levar a justiça por razões de Estado.

Eutífron: Quem te acussa?

Sócrates: Meleto. Não parecia que ele me tinha tanta inimizade. Falaram-se que me acusa de haver introduzido o culto de alguma nova divindade em detrimento de nossos velhos deuses.

Eutífron: É sem dúvida por causa dessa voz sobrenatural que diz sentir dentro de você e que te inspira. A inovação em matéria religiosa é um tipo de calúnia a que quase todos enfurecem (ROSSELLINI, 1970, $55 \min 41$ s a $59 \min 56 \mathrm{~s})$.

Esta inovação religiosa, para Sócrates, é uma acusação ilegítima. 0 que o filósofo alega sentir e escutar é a voz da razão, sua obrigação para com o conhecimento e a verdade. Eutífron e Sócrates conversam sobre a definição de piedade, uma vez que o ateniense conta ao nosso protagonista que acusou o próprio pai de homicídio pela a morte de um dos seus trabalhadores. Eutífron responde: "Piedoso é o que eu faço! Levar a justiça qualquer um que tenha cometido um crime, ainda que seja a mãe, o pai ou o filho! Zeus, o mais justo dos deuses, prendeu seu pai Urano para castigálo por ter devorado os seus próprios filhos". Sócrates lhe responde, prosseguindo em seu raciocínio lógico:

Segundo sua opinião, uma mesma coisa pode agradar a um deus e desagradar outro. Que queira castigar seu pai poderia, então, agradar a Zeus e irritar Urano, agradar a Hefesto e desagradar a Hera. Então, se entendi bem, uma mesma ação pode, ao mesmo tempo, agradar e desagradar aos deuses. É dizer, ao mesmo tempo, piedosa e ímpia, mas isso é impossível. Eu te suplico, diga-me o que é a piedade? (ROSSELLINI, $1970,55 \mathrm{~min} 41 \mathrm{~s}$ a $59 \mathrm{~min} 56 \mathrm{~s})$.

Revista Páginas de Filosofia, v. 9, n. 2, p. 69-107, jul.-dez. 2020 
Com exemplos e silogismos, Sócrates desenvolve seu raciocínio e de igual modo o faz em seu julgamento. Xântipe chama Lisías, famoso pela sua oratória, para defendê-lo, mas o filósofo se nega a aceitar ajuda e diz que proferirá sua própria argumentação contra as acusações que lhe foram feitas. A piedade, refletidade anteriormente, não se concretizou em seu destino. Sobre Sócrates e a piedade, Marly Meinberg (2003) acrescenta:

Enfim, onde está o novo alvo de seu interesse: o homem no seu agir, ou o homem na esfera do que os gregos chamam "éthos", isto é, os costumes e os comportamentos. É preciso ser piedoso, diz Atenas. E Sócrates se interroga: 0 que é a piedade? Sejamos corajosos, dizem os atenienses. E Sócrates lhes pergunta: 0 que é a coragem? Contenta-te em fazer o teu dever, diz a velha sabedoria ateniense. E Sócrates: o que é o dever? (MEINBERG, 2003, p.04).

Lisías chega a ensaiar a defesa de Sócrates e quando clama pela absolvição, a música instrumental pezarosa se inicia na atmosfera sonora. Ele pede que os "depositários da sabedoria ateniense" respeitem a velhice e as "esquisitices" de um ancião e Sócrates argumenta: "Se a democracia quer a minha morte, deverá ter suas razões. Eu lhes direi a verdade a minha maniera. Veremos se me entendem. Na minha idade, não estou para as belas palavras". Ana Elisa Pinheiro (2003), retrata em seu artigo a recusa de Sócrates à defesa de Lísias e sua sustentação oral:

Segundo Xenofonte, Sócrates começara por afirmar que nada tinha a declarar em sua defesa, porque na realidade todos conheciam que ele não era culpado dos atos de que o responsabilizavam, para se justificar depois dizendo que fora o seu daimonion ${ }^{4}$ que o impedira de se defender em termos convencionais. Também Platão confirma que Sócrates não quisera compor um discurso de defesa. Diógenes Laércio, por sua vez, refere o fato de Lísias se ter oferecido para lhe compor o discurso e de Sócrates ter recusado. Contudo, é óbvio que algumas palavras foram pronunciadas em tribunal, nem que mais não fosse para recusar a tal defesa e que é com base nesse discurso que quer Platão, que estava presente, quer Xenofonte, que conheceu o episódio de modo indireto, reescrevem o que teria sido a Apologia de Sócrates (PINHEIRO, 2003, p.143).

\footnotetext{
4 Em Platão, o daimonion é sobretudo impeditivo, uma espécie de consciência crítica que evita que Sócrates atue de modo errado. Pelo contrário, em Xenofonte, parece ser antes um guia.
}

Revista Páginas de Filosofia, v. 9, n. 2, p. 69-107, jul.-dez. 2020 
Chega o dia do julgamento, que se inicia em uma cena externa e diurna (esterno giorno), com vários cidadãos atenienses como espectadores. Jurados escolhidos pelas favas, assim como o faziam com os governantes e o Arconte-rei, acompanhado por alguns dignitários. Esta é a democracia que condenou Sócrates. 0 arauto confirma esta perspectiva quando faz as alegações inicias, dizendo: "Vós que foram eleitos pela sorte com a aquiescência dos deuses saibam que devem dar vossa sentença no processo iniciado por Meleto, e apoiado por Anito e Lícon, contra Sócrates". A cena pode ser observada nos fotogramas da imagem 8, abaixo:

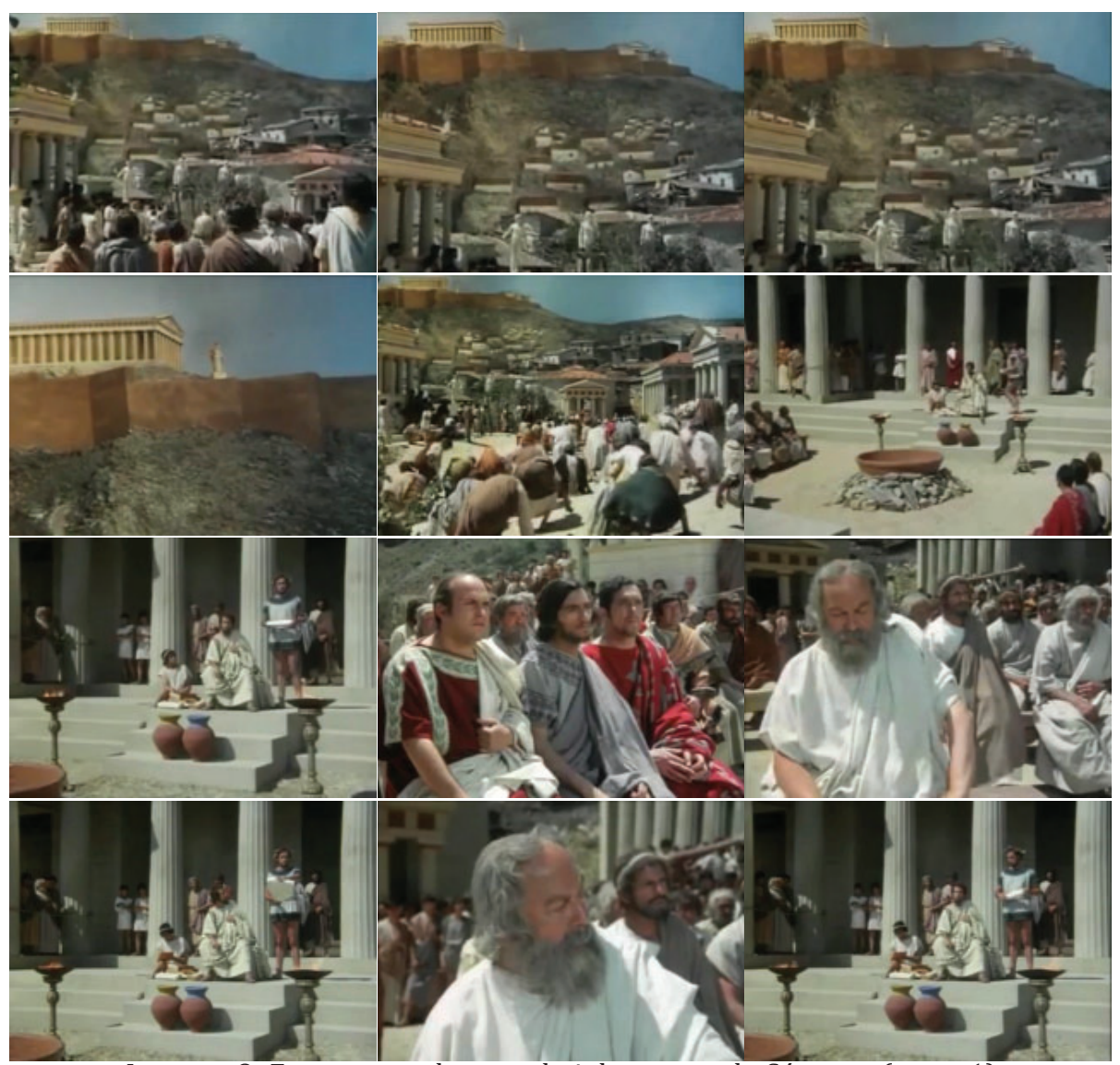

Imagem 8: Fotogramas da cena do julgamento de Sócrates (parte 1). 
Podemos observar que na prece inicial feita pelo arauto a Atena, a imagem da deusa é enquadrada com zoom em plano aberto (campo lungo). Meleto assiste ao lado de dos co-acusatores e Sócrates, que não perdeu sua doce expressão, testemunha a cena. Peter Brunette (1987) aborda em seu livro a escolha dos atores para interpretar os personagens de Sócrates por Rossellini:

Sócrates e sua esposa, Xântipe, são interpretados por atores de teatro francês, e Trasatti afirma que é sintomático da desilusão de Rossellini com a rede de televisão italiana. Rossellini disse, porém, sobre Jean Sylvère, que interpreta Sócrates: "Tinha aqueles olhos maravilhosos e ele é um bom homem. Eu precisava daqueles olhos e eu construí o rosto de Sócrates à sua volta" (Entrevista, Film Culture, 20). Sylvère, de fato, têm uma semelhança notável com a representação do padrão helenista de Sócrates encontrado em muitos bustos sobreviventes. Não está claro como essa necessidade "fidelidade" física se encaixa na abordagem de Rossellini para a história, mas parece ser outra forma de se aproximar a realidade histórica através de ideias e representações passadas e representações do que a "história" parecia ${ }^{5}$ (BRUNETTE, 1987, p.404, tradução da autora).

A semelhança entre Sócrates e Jean Sylvère ajuda na ambientação histórica da narrativa e no envolvimento dos espectadores com a narrativa. Na cena do julgamento há vários enquadramentos no filósofo enquanto este se defende das acusações impetradas por Meleto, que se esforça para não transparecer suas motivações individuais na causa:

Não é interesses pessoais que me trazem ante este tribunal para acusar do crime de impiedade nosso concidadão Sócrates. É o amor por Atenas. Sócrates pretende trocar o culto de nossos antigos deusess pelo culto de novos demônios, cuja natureza revela que sempre foi msid propenso a destruir do que a construir. Este crime, agora que recuperamos a paz,

\footnotetext{
5 Texto original em inglês: "Socrates and his wife, Xanthippe, are played by French theater actors, which Trasatti claims is symptomatic of Rossellini's disillusionment with the Italian television network. Rossellini has said, however, that Jean Sylvère, who plays Socrates, "had those wonderful eyes and he is a nice man. I needed the eyes, and I built the face of Socrates around them" (Interview, Film Culture, 20). Sylvère does indeed bear a striking resemblance to the standard Hellenistic representation of Socrates found on many surviving busts. It is unclear how this need for physical "fidelity" fits into Rossellini's approach to history, but it seems to be another way of approaching historical reality through past ideas and past representations of what "history" looked like".
}

Revista Páginas de Filosofia, v. 9, n. 2, p. 69-107, jul.-dez. 2020 
ameça desencadear contra nossa pátria, contra Atenas a justa cólera dos deuses. Com ânimo pofundamente aflito, sinto que é meu dever solicitar a pena de morte contra Sócrates. A existência de Atenas se encontra em vossas mãos (ROSSELLINI, 1970, 1h11min54s a 1h28min02s).

A ênfase dada de modo quase triunfal ao fim de Atenas busca promover, intensionalmente, o medo, atribuindo à Sócrates a responsabilidade pelo rompimento do estado de paz e equilíbrio. Anito e Lícon fazem suas colocações e a palavra é dada à Sócrates:

Disseram-lhes, atenienses, que eu sou um orador. Eu vos digo que com a minha idade, setenta anos, não faria bem em praticar a eloquência. É a primeira vez que compareço perante vós. Chamado por uma corte de justiça, mas o que já me ouviram falar nas ruas e praças poderão dizer que falo aqui como falo sempre e em todo lugar: a minha maneira, ou seja, buscando a verdade sem argucias formais. A lei exige que eu use a palavra para me defender e eu me defenderei. Sem embargo, antes de responder a meus acusadores, a quem escutei com a maior atenção, devo responder as más línguas que por mais de vinte anos insistem em me confundir com certo Sócrates, homem ocupado em estudar os mistérios da terra ou o que é talvez mais grave, em venerar as nuvens. Um personagem assim só está no espírito dos que tão maliciosamente me retrataram no palco como um ateu! (...) Apelo aqui ao testemnho dos que me conhecem. Quando se falou que me ocupo da educação de muitos jovens para cobrar honorários e para ensinar-lhes a fazer justa uma causa injusta, incorre em falsidade. $\mathrm{Eu}$, de fato me contento em buscar a verdade. (...) Desafortunadamente, sou ignorante e meu único conhecimento reside em saber que nada sei. Mas este é um tipo de conhecimento que não se pode vender. Agora, alguém poderia exclamar: Mas, diga-me, Sócrates, se não existe em você nada extraordinário por que esta calunia e este processo? E eu responderei: Porque eu possou a sabedoria (ROSSELLINI, 1970, 1h11min54s a $1 \mathrm{~h} 28 \mathrm{~min} 02 \mathrm{~s}$ ).

Quando Sócrates alega possuir a sabedoria, refere-se à indagação de Clerofonte ao oráculo de Delfos, questionando a ele se havia alguém mais sábio do que o filósofo. A Pitonisa respondeu que não havia no mundo inteiro ninguém mais sábio que ele. Sócrates atribui a resposta obtida pelo oráculo a consciência de sua ignorância e humildade, dizendo: "Eu era o mais sábio, porque todos esses políticos, esses poetas e artífices presumiam saber sem nada saber; entretanto eu, Sócrates, sempre tive consciência de minha ignorância”. Lucita Briza, em seu artigo, escreve sobre a morte de Sócrates e faz alusão à Delfos: 
Apolo, em Delfos, ouviu do oráculo que Sócrates era “o mais sábio dos homens". Deduzindo que sua sabedoria só podia ser resultado da percepção da própria ignorância, passou a dialogar com as pessoas que se dispusessem a procurar a verdade e o bem. Em meio ao desmoronamento do império ateniense e à guerra civil interna, quando já era septuagenário, Sócrates foi acusado de desrespeitar os deuses do Estado e de corromper os jovens. Julgado e condenado à morte por envenenamento, ele se recusou a fugir ou a renegar suas convicções para salvar a vida. Ingeriu cicuta e morreu rodeado por seus amigos, em 399 a.C. (BRIZA, 2011, p.04).

A cena incia-se com enquadramento em plano americano e, depois, passa para o primeiro plano com zoom na figura de Sócrates quando este inicia, suave e tranquilamente sua fala. Após o testemunho do irmão de Clerofonte e vende a receptividade do público espectador, Meleto visivelmente se altera, levanta de seu assento e se dirige ao lado de Sócra tes para tomar-lhe a palavra, como podemos observar na imagem 9, abaixo:

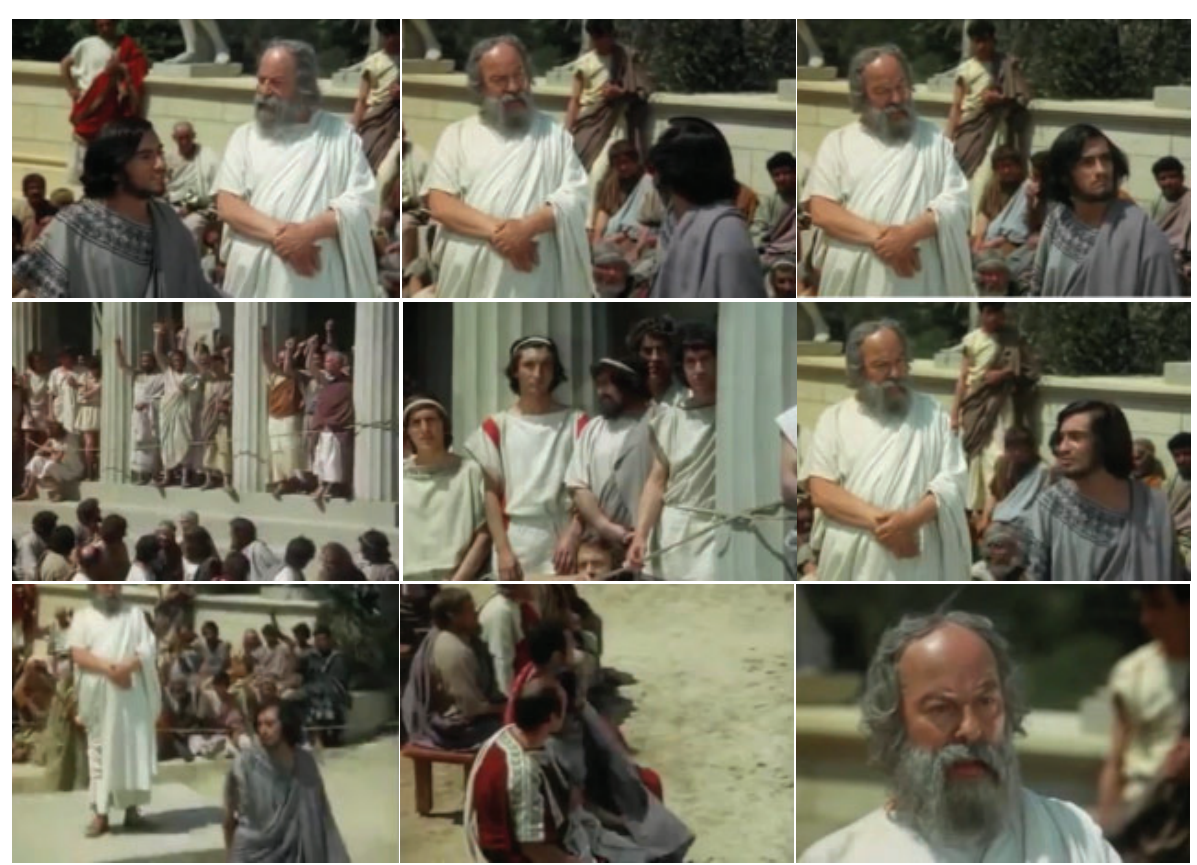

Imagem 9: Fotogramas da cena do julgamento de Sócrates (parte 2). 
Sócrates questiona sua infliência sobre a juventude, diretamente Meleto: "Em suma, todos os atenienses têm boa influência sobre a juventude. Todos, salvo Sócrates, que ao contrário a corrompe, não é o que diz?". Meleto responde, prontamente: "Sim, e com todas as minhas forças!". O filósofo completa seu raciocínio, mostrando aos espectadores que a argumentação feita por Meleto durante o julgamento não se sustenta, carece de raciocínio lógico:

Ah, que pobre homem este Sócrates! Que horrível destino! E que grande felicidade se é verdade que todos na cidade têm boa influência sobre a juventude, e que um só homem, este Sócrates, a corrompe! Acaba de demostrar, Meleto, que não tem o mínimo conhecimento dos problemas pelos quais você iniciou o processo (ROSSELLINI, 1970, 1h11min54s a $1 \mathrm{~h} 28 \mathrm{~min} 02 \mathrm{~s})$.

Sócrates ainda insiste: "Acusando-me de corromper a juventude é o mesmo de acusar-me de fazer o mal a ela. Crê que eu a corrompa voluntaria ou involuntariamente?" Mais uma vez, Meleto não hesita em responder: "Voluntariamente, isso é certo!". E Sócrates, com astúcia:

Como é isso, Meleto? Sabe que os maus fazem mal a todos os que os cercam e espera que na minha idade eu não saiba disso? Crê então que fazendo mal aos que me rodeiam não sei que me exponho ao perigo de ser maltratado por eles? Não. Ou não corrompo a juventude, ou bem se o faço, é sem querer e em tal caso, esta culpa é involuntária e não é de competência deste tribunal (ROSSELLINI, 1970, 1h11min54s a 1h28min02s).

A platéia apoia o filófoso, bradando: "Bem dito, Sócrates! Tens razão!". 0 diálogo prossegue e Socrates finaliza sua fala com coragem: "A acusação de Meleto não é nada mais do que uma calúnia. Esta calúnia pode dar-me a morte, mas ante a vós, não penso em comportar-me como um covarde". E assim o fez, quando o arauto do Arconte rei proferiu sua sentença: "De acordo com o escrutínio, Sócrates é declarado culpado por uma maioria de sessenta votos". O filósofo tem novamente a palavra, mas nada faz mudar a percepção dos jurados que o temem e o anuncio da morte próxima é declarado perante todos. Sócrates aguardará preso até que a barca sagrada que comemora a vitória de Teseu sobre o Minotaurdo retorne de Delos. Sócrates adverte os espectadores: 
Cidadãos de Atenas, se tivessem esperado um pouco mais a morte os teria libertado de mim por si só. Saudemos esta assembleia, eu condenado a morte, e você, meus juízes, condenados pela verdade. E todas as nossas vidas ficarão marcadas pela injustiça que agora cometeram (ROSSELLINI, 1970, 1h11min54s a 1h28min02s).

Já na prisão, Críton visita Sócrates e tenta persuadí-lo a fugir, alegando que os guardas não iram impor resistência. Ele planeja levar o filósofo a Tessália, mas ele recusa, dizendo que se será morto é culpa dos homens, não das leis. No dia de sua execusão, Xântipe leva seus filhos para se despedirem do pai, como ilustra a imagem 10, abaixo:

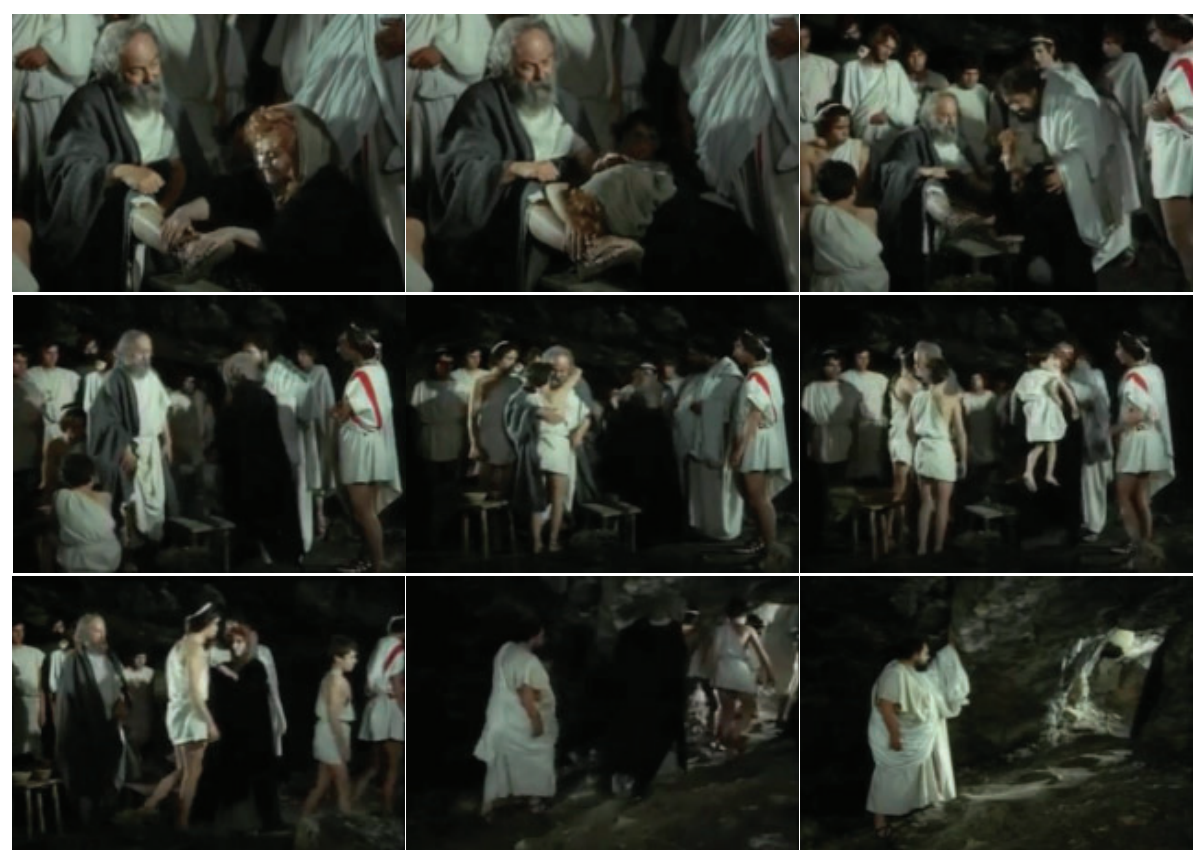

Imagem 10: Fotogramas da cena na qual Sócrates se despede de Xântipe e de seus amigos na prisão.

O que Sócrates diz aos seus filhos não nos é revelado. Eles se abraçam, Xântipe se emociona. Uma cena que ganha destaque na análise crítica de Peter Brunette (1987) é a famosa cena da morte de Sócrates, quando este ingere a cicuta. Mostra-se a importância da tomada 
longa para a cena e uma reflexão sobre a presença do zoom na cena final do filme. Sem dúvida este é o filme mais humano da coleção "Os Filósofos" do diretor:

Esta é a primeira vez que Rossellini tenta transmitir a essência de um filósofo, uma tentativa ázima, ao contrário de Pascal e Agostinho de Hipona, que trazem informações de natureza mais biográficas. (...) Certas partes do filme são tão lentas que uma pessoa se torna consciente de que muitas vezes o zoom está desesperadamente tentando criar uma distração visual, entrando e saindo sem uma boa razão. (Significativamente este filme contém muitos mais close-ups do que a maioria dos outros filmes históricos, em um esforço para fornecer a variedade visual e para enfatizar o que está sendo dito). No entanto, há outros momentos "lentos" neste filme que funcionam belissimamente. 0 melhor exemplo ocorre perto do final, quando Sócrates está andando para trás e o efeito da cicuta está trabalhando em suas pernas. A cena parece continuar para sempre, mas é tão "humano" (em oposição a uma versão mais convencional, onde o veneno haveria de trabalhar de imediato, de modo a evitar qualquer tempo para a morte), que são fixadas $^{6}$ (BRUNETTE, 1987, p.300-301, tradução da autora).

0 apelo emocional também está presente na cena que mostra Xântipe acalentando seus filhos que choram pela perda próxima do pai, em frente ao portão do presídio. Ao lado dela esta Apolodoro. Ela mostra grande coragem na frente das crianças e lhes diz, com os olhos marejados: "Não chore. Seu pai não chora. Pensem na lição que

\footnotetext{
6 Texto original em inglês: "This is the first time that Rossellini attempts to convey the essence of a philosopher, an attempt that is unleavened, unlike in Pascal and Augustine of Hippo, with information of a more biographical nature. (...) Certain parts of the film are simply uninteresting, and so slow that one becomes aware that often the zoom is desperately trying to create a visual diversion, moving in and out for no good reason. One is never at ease with the flat, visually dead long takes of Socrates as one is with the pregnant long takes of the rest of Rossellini's career. (Significantly, this film contains many more close-ups than most of the other historical films, in an effort to provide visual variety and to emphasize what is being said.) Yet there are other "slow" moments in this film that function beautifully. The best example occurs near the end, when Socrates is walking back and forth to get the hemlock working in his legs. The scene seems to go on forever, yet it is so "human" (as opposed to a more conventional version, where the poison would work right away so as to avoid any possible dead time), that we are riveted".
}

Revista Páginas de Filosofia, v. 9, n. 2, p. 69-107, jul.-dez. 2020 
lhes ensinou. Em sua coragem. Quando forem grandes, todos terão os olhos fixos sobre vocês porque são os filhos de Sócrates, o cidadão mais valoroso de Atenas". Esta cena pode ser observada nos fotogramas da imagem 11, a seguir:

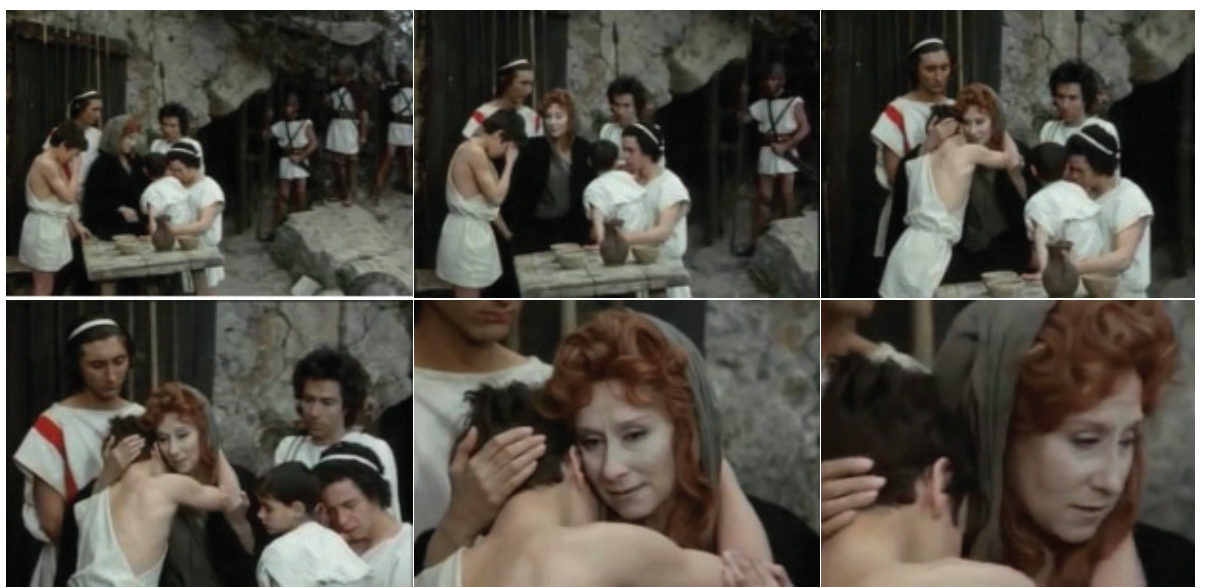

Imagem 11: Fotograma da cena que mostra Xântipe consolando seus filhos.

Sócrates, também confiante e sereno, se prepara para tomar a cicuta e diz suas últimas palavras, vestindo a túnica com a qual morrerá. Xântipe suplica: “Oh! Não! Vais morrer injustamente!”. Seu marido lhe indaga: "Preferia ver-me morrer justamente?". Após a despedida, Sócrates pergunta ao seu carrasco: "Meu amigo, sois a autoridade em matéria de veneno. 0 que faço?". Ele responde: "Assim que beber, caminha até sentir as pernas pesadas, então recosta e deixa a cicuta agir". Sócrates caminha pela sua cela aguardando o fim eminente (imagem 12):

Quando sente o efeito do veneno, discursa uma última vez: "Os homens caluniam os cisnes. Na hora da morte, os cisnes não cantam de desespero, mas sim porque são felizes de ir embora com os deuses, a serví-los. Já me pesam as pernas". Sócrates se deita e seus seguidores cobrem-lhe o corpo com um sudário. 0 filósofo descobre sua cabeça e diz suas palavras finais, dirigindo-se a Criton como se tivesse se esqueciso de algo: "Bom Críton, nós devemos um galo a Asclépio, não se esqueça”. Esta cena pode ser observada na imagem 13, a seguir: 

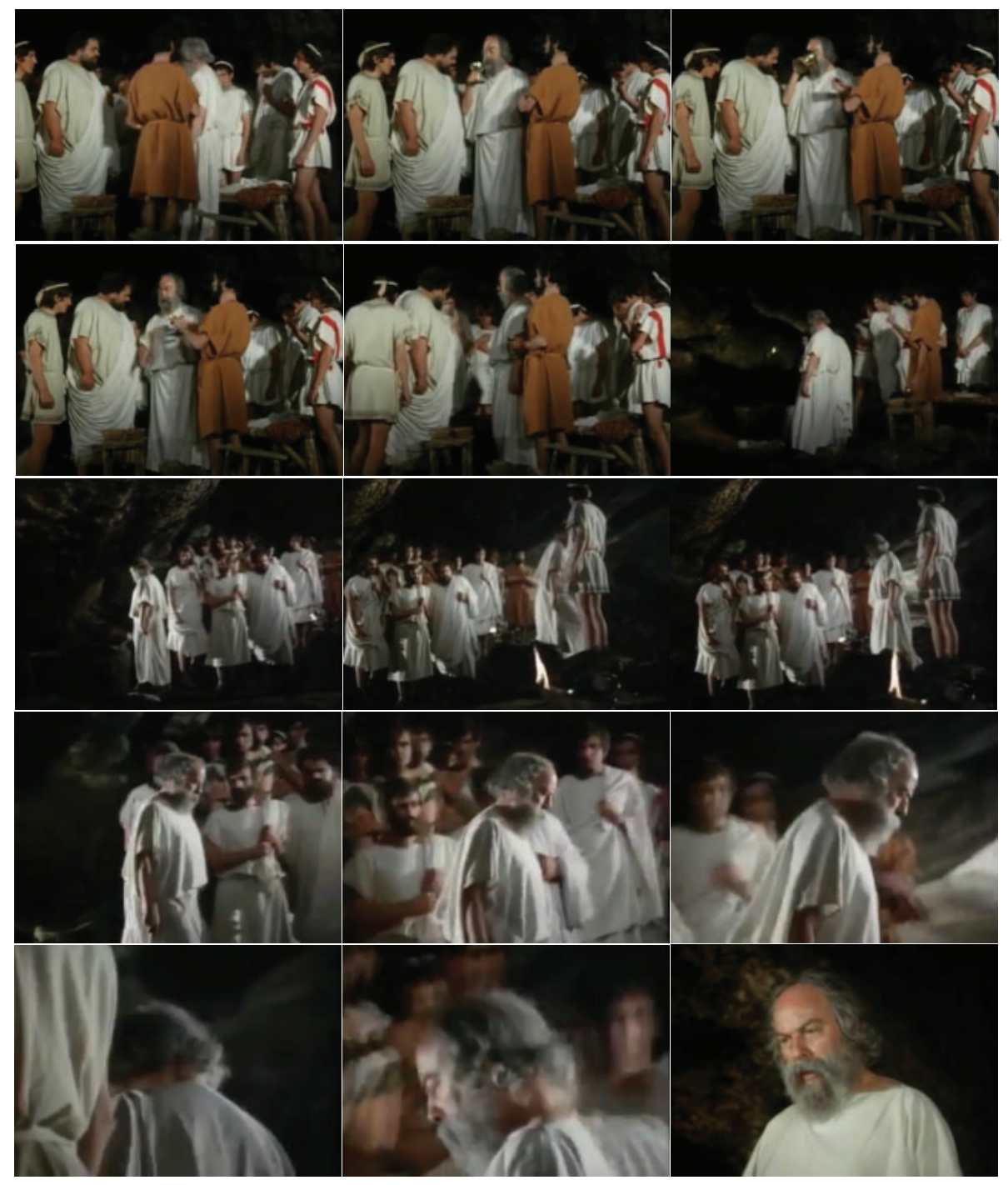

Imagem 12: Fotogramas da cena que mostra Sócrates caminhando após a ingestão da cicuta. 


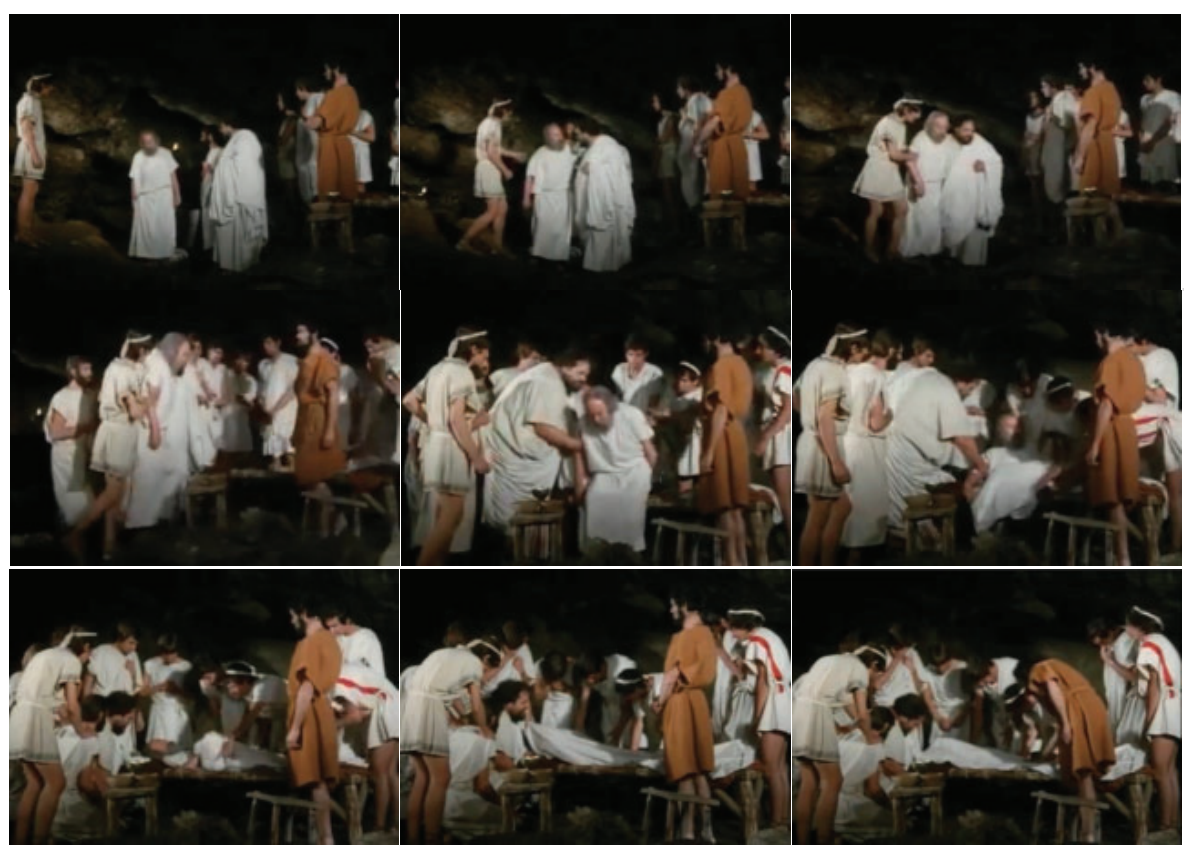

Imagem 13: Fotogramas da cena que mostra a morte de Sócrates pela cicuta.

Sócrates morre e o fim se atrela ao início da narrativa na atmosfera sonora, voltando os sons dos tambores agora, quebrando o silêncio da tristeza da cena. A sentença foi executada, mas a alusão do filósofo a Asclépio, deus da cura e da medicina, que tem o poder te dar vida aos mortos, deixa claro que apesar da morte física, Sócrates entra para a história e seus conhecimentos e a verdade pela qual lutou estarão presentes.

\section{Considerações Finais}

Nas palavras de Roberto Rossellini: "Todo o conhecimento começa com os olhos, embora o frescor de nossas primeiras percepções seja logo obscurecido. (...) Meu objetivo principal é recuperar a enorme inocência do olhar original, a primeira imagem que apareceu aos nossos olhos". Esta imagem o diretor denominou a "imagem essencial", aquela fora do alcance das expectativas conceituais ou verbais, oposta a "ilustração". Outra antítese advinda de um homem conflituoso em 
sua essência e ansioso pela verdade como os filósofos que procurou retratar em suas cinebiografias.

$\mathrm{Na}$ escolha das cenas para análise, deu-se preferência àquelas que versam sobre a as reflexões filosóficas feitas por Sócrates, principalmente no seu julgamento e no fim de sua vida e que marcaram significativamente a filosofia antiga.

Roberto Rossellini faz a seguinte reflexão em sua biografia: "O que realmente me interessava era o personagem; e o personagem deveria viver em certo contexto que eu queria descobrir com ele." (NETO, 2007, p.04). Com a análise do filme de Sócrates pudemos observar que este objetivo de aprendizado se concretiza, principalmente nos enquadramentos das cenas, como esmiúça Alcino Leite Neto (2007), utilizando-se de uma declaração do próprio diretor:

Habitualmente, no cinema tradicional corta-se uma cena do seguinte modo: plano geral, e se define o ambiente, se descobre um indivíduo, se aproxima dele; plano médio, plano americano, primeiro plano, e se começa a contar a sua história. Eu procedo de maneira oposta: um homem se posta e, graças à sua posição, descobrimos o ambiente em que ele se encontra. Começo sempre com um primeiro plano, depois o movimento da câmera acompanha o ator e descobre o ambiente (NETO, 2007, p.7-8).

Rossellini pôde não ter seguido obrigatoriamente a ordem de planificação citada acima, mas é certo que o diretor jamais deixou a necessidade de, em seus filmes, estar sempre ao lado do personagem, descrevendo cuidadosamente e em detalhes o ambiente em que ele se movimenta no momento mesmo em que o contexto vai se revelando ao protagonista. Um "mágico do real" como denominou-o David Forgacs, professor de italiano na University College em Londres.

\section{REFERÊNCIAS}

AUMONT, Jacques; MARIE, Michel. A análise do filme. Edições Texto \& Grafia, Lisboa, 2004.

BRIZA, Lucita. Educar para crescer: Sócrates, Revista Nova Escola, 2011.

CRESCI, Gian Paolo. La TV di Rossellini. Coines Edizioni: Roma, 1972

Revista Páginas de Filosofia, v. 9, n. 2, p. 69-107, jul.-dez. 2020 
CRUCHINHO, Fausto. A televisão de Roberto Rossellini. In: Estudos do Século XX, n.7, p.319-335, 2007.

MEINBERG, Marly. Sócrates: A individualidade na Grécia. Revista Philosophica, n.26. Instituto de Filosofia Pontifícia Universidade Católica de Valparaíso, 2003.

MELO, Luís Fernando. Sócrates: 0 mestre grego e seu sistema pedagógico refletindo na educação contemporânea. Uberlândia: Faculdade Católica de Uberlândia, 2006.

NETO, Alcino Leite. Errância e construção do espaço no cinema moderno - Uma leitura da obra de Roberto Rossellini, São Paulo, 2007.

PINHEIRO, Ana Elias. Xenofonte, apologia de Sócrates. Mathesis, v.12, p.133-164, 2003. PLATÃO. Apologia de Sócrates. Êutifron. Críton, Lisboa, Verbo, 1972.

ROSSELLINI, Roberto. Fragmentos de uma autobiografia. Posfácio Stefano Roncoroni; Tradução de Léa Novaes. Rio de Janeiro: Nova Fronteira, 1992.

\section{Filmografia}

Socrate (1970) de Roberto Rossellini. Disponível em: https://www.youtube.com/ watch?v=5TaaT30L8yg 